\title{
Spatial productivity variations during formation of sapropels S5 and S6 in the Mediterranean Sea: evidence from $\mathrm{Ba}$ contents
}

\author{
Syee Weldeab ${ }^{\mathrm{a}, \mathrm{b}, *}$, Kay-Christian Emeis ${ }^{\mathrm{b}}$, Christoph Hemleben ${ }^{\mathrm{a}}$, \\ Gerhard Schmiedl ${ }^{\mathrm{a}}$, Hartmut Schulz ${ }^{\mathrm{b}}$ \\ a Institute for Geosciences, University of Tuebingen, Tuebingen, Germany \\ b Institute for Baltic Sea Research Warnemuende, Rostock-Warnemuende, Germany
}

Received 29 October 2001; accepted 3 December 2002

\begin{abstract}
We investigated five time-equivalent core sections (180-110 kyr BP) from the Balearic Sea (Menorca Rise), the easternmost Levantine Basin and southwest, south, and southeast of Crete to reconstruct spatial patterns of productivity during deposition of sapropels S5 and S6 in the Mediterranean Sea. Our indicators are Ba, total organic carbon and carbonate contents. We found no indications of Ba remobilization within the investigated core intervals, and used the accumulation rate of biogenic Ba to compute paleoproductivity. Maximum surface water productivity (up to $350 \mathrm{~g} \mathrm{C} / \mathrm{m}^{2} / \mathrm{yr}$ ) was found during deposition of $\mathrm{S} 5$ (isotope stage $5 \mathrm{e}$ ) but pronounced spatial variability is evident. Coeval sediment intervals in the Balearic Sea show very little productivity change, suggesting that chemical and biological environments in the eastern and western Mediterranean basins were decoupled in this interval. We interpret the spatial variability as the result of two different modes of nutrient delivery to the photic zone: riverderived nutrient input and shoaling of the pycnocline/nutricline to the photic zone. The productivity increase during the formation of S6 was moderate compared to S5 and had a less marked spatial variability within the study area of the eastern Mediterranean Sea. Given that S6 formed during a glacial interval, glacial boundary conditions such as high wind stress and/or cooler surface water temperatures apparently favored lateral and vertical mixing and prevented the development of the spatial gradients within the Eastern Mediterranean Sea (EMS) observed for S5. A non-sapropel sediment interval with elevated $\mathrm{Ba}$ content and depleted ${ }^{18} \mathrm{O} /{ }^{16} \mathrm{O}$ ratios in planktonic foraminifer calcite was detected between S6 and S5 that corresponds to the weak northern hemisphere insolation maximum at 150 kyr. At this time, productivity apparently increased up to five times over surrounding intervals, but abundant benthic fauna show that the deep water remained oxic. Following our interpretation, the interval denotes a failed sapropel, when a weaker monsoon did not force the EMS into permanent stratification. The comparison of interglacial and glacial sapropels illustrates the relevance of climatic boundary conditions in the northern catchment in determining the facies and spatial variability of sapropels within the EMS.
\end{abstract}

(c) 2003 Elsevier Science B.V. All rights reserved.

\footnotetext{
* Corresponding author. Present address: Fachbereich Geowissenschaften, P.O. Box 3304 40, 28334 Bremen, Germany. Tel.: +49-421-2188911; Fax: +49-421-2188916.

E-mail address: sweldeab@uni-bremen.de (S. Weldeab).
} 
Keywords: Mediterranean Sea; sapropels; biogenic barium; productivity changes

\section{Introduction}

The modern Mediterranean Sea is a highly oligotrophic marine environment and the flux of organic carbon to the surface sediment is very low. However, dramatic and short-term increases in the burial of organic carbon have occurred since 5.3 million years ago at intervals corresponding to northern hemisphere insolation maxima, increased seasonal contrasts and intensified runoff (Rossignol-Strick et al., 1982; Rossignol-Strick, 1983; Hilgen, 1991; Lourens et al., 1996; Emeis et al., 2000a,b). During these periods which lasted several thousands of years (Vergnaud-Grazzini et al., 1977), organic-rich $\left(\mathrm{C}_{\text {org }} \sim 30 \%\right)$ sediments also known as sapropels (Kullenberg, 1952; Olausson, 1961; Kidd et al., 1978) were deposited. The exact mechanisms leading to an enhanced accumulation rate of organic matter are still under debate and concentrate on either anoxia as the primary cause of sapropel formation (for instance Nolet and Corliss, 1990; Tang and Scott, 1993; Sachs and Repeta, 1999) or on changes in productivity (Rohling and Hilgen, 1991, Martinez-Ruiz et al., 2000). In its most rigorous form, the anoxia hypothesis states that the increase in total organic carbon (TOC) is caused solely by enhanced preservation of organic matter and reduced input of lithogenic material during sapropel formation. This view is based on the extraordinarily high pollen counts in sapropels that argue against an increase in marine productivity (Cheddadi and Rossignol-Strick, 1995). In contrast, several lines of evidence suggest that the export flux of marine organic matter was increased during sapropel formation: Ryan and Cita (1977) calculated that the amount of organic carbon annually sequestered in the Mediterranean Sea during sapropel formation $\left(1.6 \times 10^{6} \mathrm{t} / \mathrm{a}\right)$ surpassed the amount of carbon annually deposited in all other pelagic basins of the world's ocean. At a modern rate of new production of $12 \mathrm{~g} \mathrm{C} / \mathrm{m} / \mathrm{a}$ for the Eastern Mediterranean (Bethoux, 1989), an improbable $30 \%$ of new production would have been buried in the sediments. Productivity levels calcu- lated from accumulation rates of organic carbon during sapropel deposition exceeded modern productivity in the Mediterranean Sea by far (Emeis et al., 1998); benthic foraminifer assemblages prior to and after anoxic periods are also indicative of enhanced carbon flux to the sea floor (Schmiedl et al., 1998). Isotopic (Calvert et al., 1992) and geochemical (Thomson et al., 1999; Wehausen and Brumsack, 1999; Nijenhuis and De Lange, 2000) evidence is also consistent with enhanced productivity during formation of sapropels.

Various alternatives have been proposed to supply the nutrients necessary to form sapropels. Circulation reversal (Calvert, 1983; Sarmiento et al., 1988; Calvert et al., 1992), upwelling (Schrader and Matherne, 1981; Fontugne and Calvert, 1992), and enhanced riverine nutrient input (Krishnamurthy et al., 2000; Martinez-Ruiz et al., 2000) have been proposed as possible mechanisms of nutrient supplement. Rohling and Gieskes (1989) presented a model of sapropel generation in which pycnocline shoaling allows injection of nutrient-enriched intermediate water (IMW) into the lower photic zone promoting high export productivity. A diminished ventilation rate would allow deep water anoxia and facilitate the preservation of organic matter.

However, whether the above mentioned modes of nutrient delivery are mutually exclusive, whether they are valid for each sub-basin of the (eastern) Mediterranean Sea and whether they are applicable to each individual sapropel is as yet poorly understood.

The objective of this study is to reconstruct spatial and temporal productivity changes and to infer the mode of nutrient delivery to the Mediterranean Sea at times of sapropel S5/S6 formation. For this purpose we used the variation of barium contents and accumulation rates as a tool for productivity reconstruction. Five core sections from different basins within the Mediterranean Sea containing sapropel 5 (S5), sapropel 6 (S6) (or time-equivalent sections) as well as nonsapropel sediments above and beneath the sapropels were investigated. Sapropel S6 formed during 


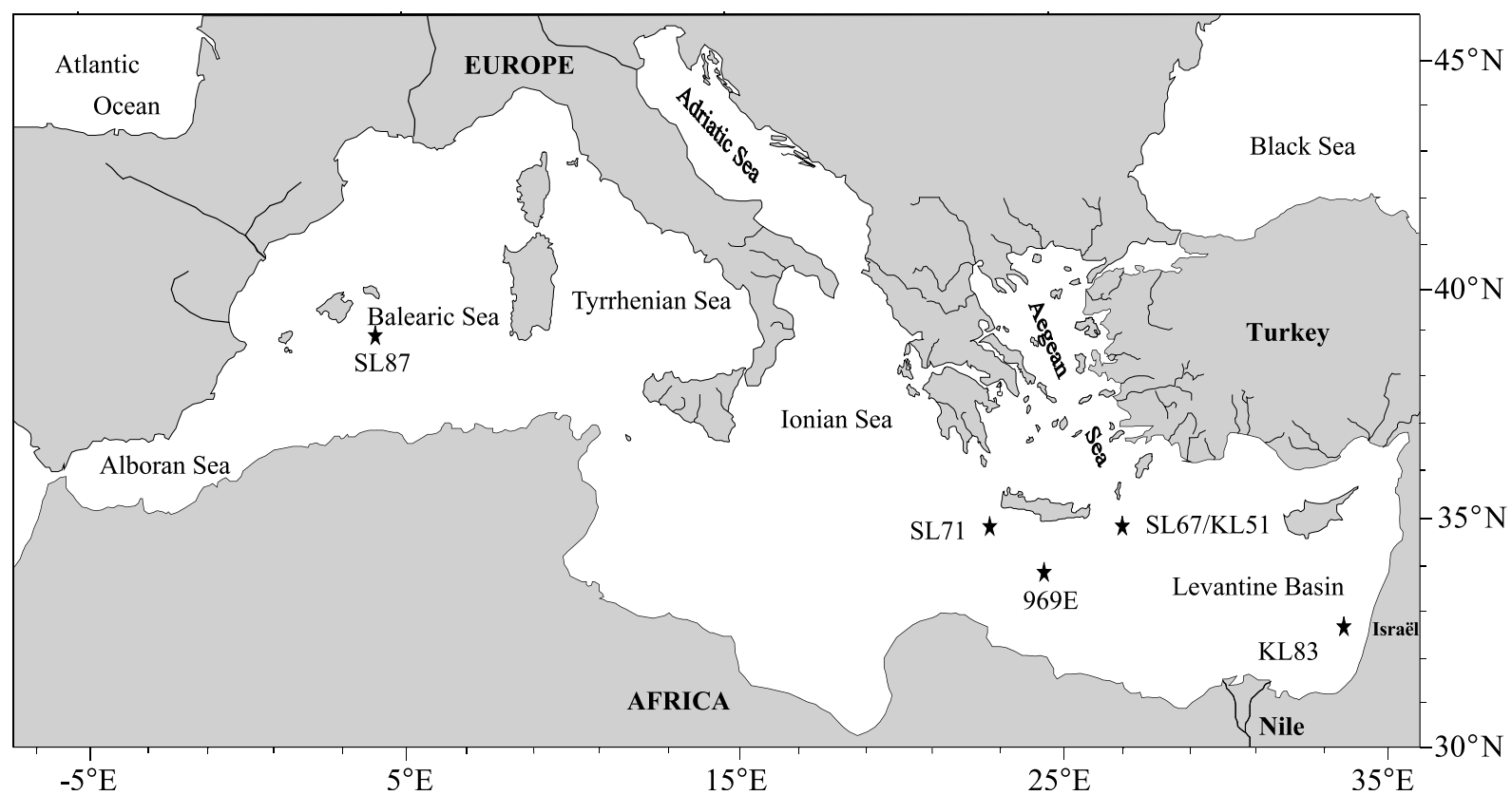

Fig. 1. Map showing the location of the five studied cores.

the fully glacial conditions of marine isotope stage (MIS) 6 (starting $176 \mathrm{kyr}$ ago) and S5 was deposited during the Eemian warm phase (starting 127 kyr ago). The core locations cover potential entrances of fresh water from northern and southern catchment areas into the Eastern Mediterranean Sea (EMS). The spatial comparison of productivity changes in comparison to the fresh water sources allows us to assess the relative importance of different modes of nutrient delivery. The patterns of productivity changes during S5 and S6 can provide valuable hints on the role of interglacial/ glacial boundary conditions in determining the intensity of sapropel formation. Furthermore, the comparison of EMS records to a time-equivalent core section from the Western Mediterranean Sea (WMS)/Balearic Sea sheds light on basin-specific amplifying or attenuating effects at times of sapropel formation.

\section{Materials and methods}

\subsection{Sampling and sample preparation}

Gravity and piston cores were recovered during
R/V Meteor expeditions M40/4 (spring 1998) and M44/3 (spring 1999). Core 969E was recovered during ODP Leg 160 (Emeis et al., 1996). Core locations are shown in Fig. 1 and listed in Table 1. Two parallel series of sub-samples were taken from the cores for inorganic geochemistry and stable isotope analysis using $10-\mathrm{ml}$ syringes at a sample spacing of $2 \mathrm{~cm}$. After determining the water content of the sub-samples, they were dried at $105^{\circ} \mathrm{C}$ for $48 \mathrm{~h}$. Subsequently to the determination of their weight loss, wet and dry bulk densities were calculated.

\subsection{Oxygen isotope stratigraphy}

Stable oxygen isotope ratios of calcareous fora-

Table 1

Core No., position, and water depth of the investigated cores

\begin{tabular}{llll}
\hline Core No. & $\begin{array}{l}\text { Latitude } \\
(\mathrm{N})\end{array}$ & $\begin{array}{l}\text { Longitude } \\
(\mathrm{E})\end{array}$ & $\begin{array}{l}\text { Water depth } \\
(\mathrm{m})\end{array}$ \\
\hline KL83 & $32^{\circ} 36.87$ & $34^{\circ} 08.89$ & 1431 \\
SL67/KL51 & $34^{\circ} 48.91$ & $27^{\circ} 17.77$ & 2158 \\
ODP 969E & $33^{\circ} 50.46$ & $24^{\circ} 52.98$ & 2212 \\
SL71 & $34^{\circ} 48.67$ & $23^{\circ} 11.63$ & 2827 \\
SL87 & $38^{\circ} 59.34$ & $04^{\circ} 01.40$ & 1900 \\
\hline
\end{tabular}




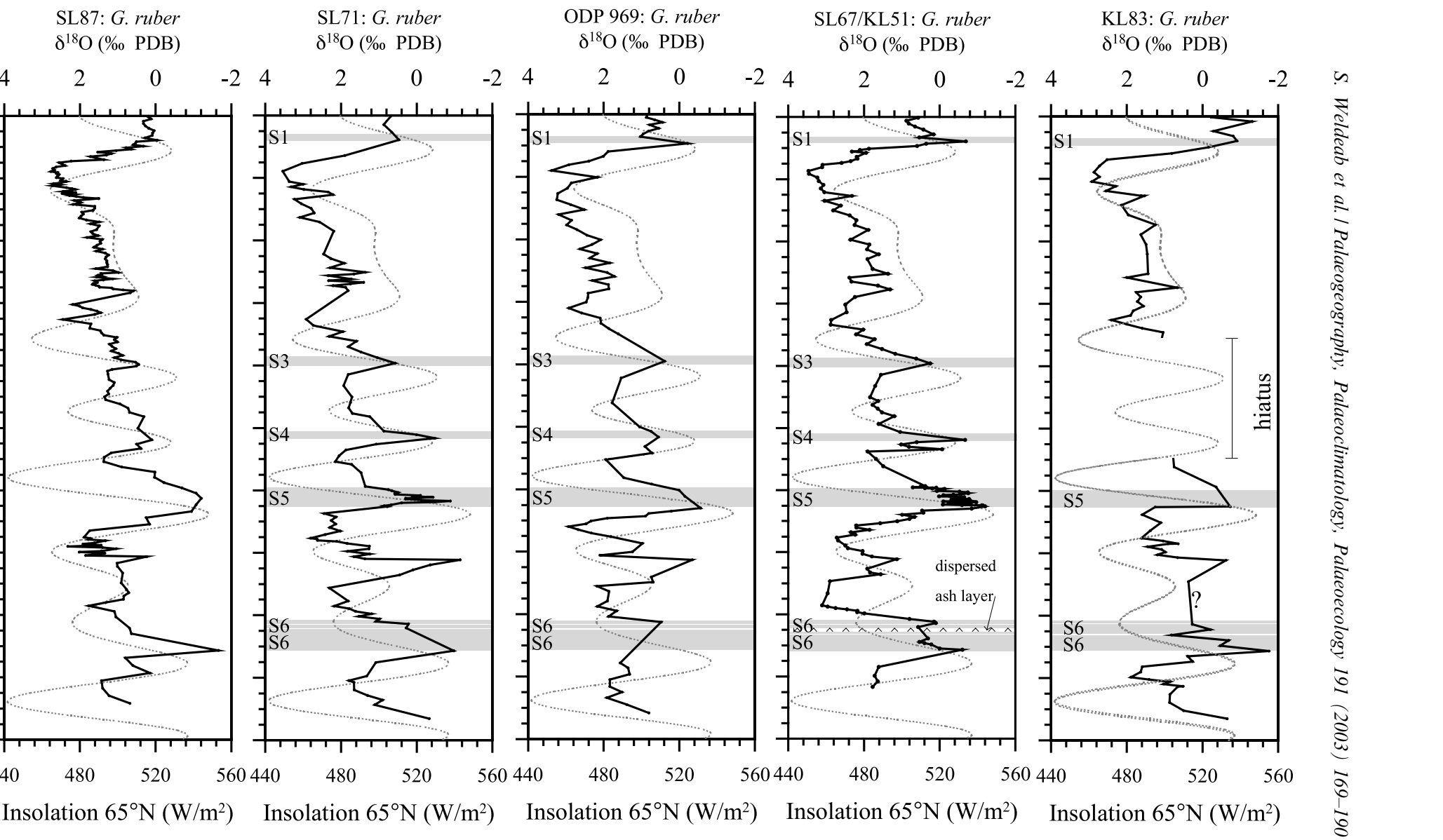

Fig. 2. Stable oxygen isotope records of Globigerinoides ruber (white) from the investigated cores versus interpolated age. The northern hemisphere summer insolation at $65^{\circ} \mathrm{N}$ is given for comparison (Berger, 1978). Dark-shaded areas show the position of sapropels. Note the hiatus in KL83. Stable isotope data for core SL71, SL67/KL51, and KL83 were taken from Weldeab et al. (2002) and for 969E from Emeis et al. (in press). 
miniferal tests were analyzed to establish the stratigraphic framework of the investigated cores. Between 10 and 17 tests of the planktic foraminifer Globigerina ruber (white) were picked from the size fraction $>250 \mu \mathrm{m}$ and ultrasonically cleaned. In core sections where Globigerinoides ruber (white) was not available Globigerinoides bulloides was used. The samples were analyzed using an automated carbonate device linked to a Finnigan MAT 251 mass spectrometer at the Leibniz Laboratory for Radiometric Dating and Stable Isotope Research, University of Kiel, Kiel, Germany. External reproducibility for stable oxygen isotopes was $<0.03 \%$. In the core section where the tests of G. ruber (white) and G. bulloides were analyzed, the $\delta^{18} \mathrm{O}$ signal of $G$. ruber was adjusted to that of $G$. bulloides by adding a total vital effect of $0.85 \%$ o ( $0.5 \%$ o for G. bulloides according to Hemleben et al. (1989) and $-0.35 \%$ for G. ruber according to Deuser and Ross (1989)). The age models for the cores are based on a graphic correlation of the $\delta^{18} \mathrm{O}$ curves with the SPECMAP isotope curve of Martinson et al. (1987) using the software package 'AnalySeries' (Paillard et al., 1996). Ages were calculated by linear interpolation between fixed points of SPECMAP events.

\subsection{TOC and carbonate analyses}

Total inorganic carbon (TIC) was measured with an 'Eltra C-S 500' C-S Analyzer by acid digestion followed by coulometric determination of the evolved $\mathrm{CO}_{2}$. To check the precision and accuracy of the analyses, replicate sample and standard measurements were performed. The precision and accuracy were $\pm 0.1 \%$ and $\pm 0.2 \%$, respectively. Total carbon (TC) analyses with the C-S Analyzer were carried out by combustion at $1200^{\circ} \mathrm{C}$, followed by coulometric determination of the evolved $\mathrm{CO}_{2}$. The difference between $\mathrm{TC}$ and TIC was assumed to originate from the combustion of organic matter. Reproducibility of analyses was better in the organic-rich sediments (sapropels) than in the organic-poor sediments. Both precision and accuracy were comparable to that of TIC determination.
2.4. X-ray fluorescence (XRF) analyses of major and minor elements

For XRF analyses $800 \pm 5 \mathrm{mg}$ of the powdered and homogenized sample was ignited in a combustion oven, ramped to $1050^{\circ} \mathrm{C}$. After 70 min combustion the samples were cooled to room temperature and re-weighed for loss on ignition. Thereafter, the material was mixed with $2000 \pm 5 \mathrm{mg}$ lithium metaborate $\left(\mathrm{LiBO}_{2}\right)$ and $1932 \pm 5 \mathrm{mg}$ di-lithium tetra-borate $\left(\mathrm{Li}_{2} \mathrm{~B}_{4} \mathrm{O}_{7}\right)$ and fused to glass discs in Pt crucibles. The glass discs were analyzed at the Institute for Geological Sciences of the University Greifswald using a Philips PW 2404 XRF spectrometer. The accuracy and precision were checked by international standards and replicate analyses of sediment samples, respectively. The analytical accuracy was within $1 \%$ of certified values. Precision was better than $3 \%$ for all elements. In order to use the barium variation as an indicator for productivity change, biogenic mediate barium $\left(\mathrm{Ba}_{\mathrm{bio}}\right)$ and barium of nonbiogenic origin have to be distinguished. Normalizing to conservative elements such as $\mathrm{Al}$ and/or $\mathrm{Ti}$ is often used to assess the terrigenous barium (e.g. Gingele et al., 1999). Based on the $\mathrm{Ba}$ and $\mathrm{Al}$ content of surface sediments and assuming that $\mathrm{Al}$ in the sediments originates from aluminosilicates, we consider a detrital ratio of $\mathrm{Ba} / \mathrm{Al}=0.002$ to be reasonable. $\mathrm{Ba}_{\text {bio }}$ flux rate $\left(\mathrm{Ba}_{\mathrm{bio}}-\mathrm{FR}\right)$, export productivity $\left(P_{\text {new }}\right)$ and primary productivity $(\mathrm{PP})$ were calculated applying an algorithm developed by Dymond et al. (1992) and modified by Francois et al. (1995). For the determination of primary productivity an equation developed by Berger et al. (1989) was used:

$$
\begin{aligned}
& \mathrm{Ba}_{\text {bio }}=\mathrm{Ba}_{\text {measured }}-\mathrm{Al}_{\text {measured }} *(\mathrm{Ba} / \mathrm{Al})_{\text {detrital }}, \\
& \text { where }(\mathrm{Ba} / \mathrm{Al})_{\text {detrital }}=0.002 \\
& \mathrm{Ba}_{\text {bio flux }}=\mathrm{Ba}_{\text {acc. }} / 0.209 \log \mathrm{MAR}-0.213 \\
& P_{\text {new }}=1.95\left(\mathrm{Ba}_{\text {bio flux }}\right)^{1.41} \\
& P_{\text {new }}=\mathrm{PP}^{2} / 400-\mathrm{PP}^{3} / 340000
\end{aligned}
$$




\section{Results}

3.1. Oxygen isotope records, age models, and sedimentation rates

The $\delta^{18} \mathrm{O}$ records resemble the global variation of the SPECMAP isotope curve (Martinson et al., 1987), but glacial-interglacial amplitudes in our core are high compared to those of the open ocean and vary between 4 and $4.6 \%$ (Fig. 2). The oxygen isotope records are marked by very low $\delta^{18} \mathrm{O}$ values (up to $-1.7 \%$ ) during sapropel formation in the EMS and time-equivalent intervals in the Balearic. This is particularly obvious during formation of sapropels S5 and S6 (Fig. 2). The northern hemisphere summer insolation values at $65^{\circ} \mathrm{N}$ are also shown in Fig. 2. The onset of each episode of sapropel formation correlates with the maximum of the insolation values assuming a time lag of 1-3 kyr between climate forcing (insolation) and maximum climate response (sapropel formation) (Hilgen, 1991; Rossignol-Strick and Paterne, 1999).

Accumulation rates in cores SL71 and SL67/ KL51 are highest during S5 and display values between $13 \mathrm{~cm} / \mathrm{kyr}$ and $6 \mathrm{~cm} / \mathrm{kyr}$, respectively (Fig. 3). KL83 is generally characterized by higher sedimentation rates relative to the other cores

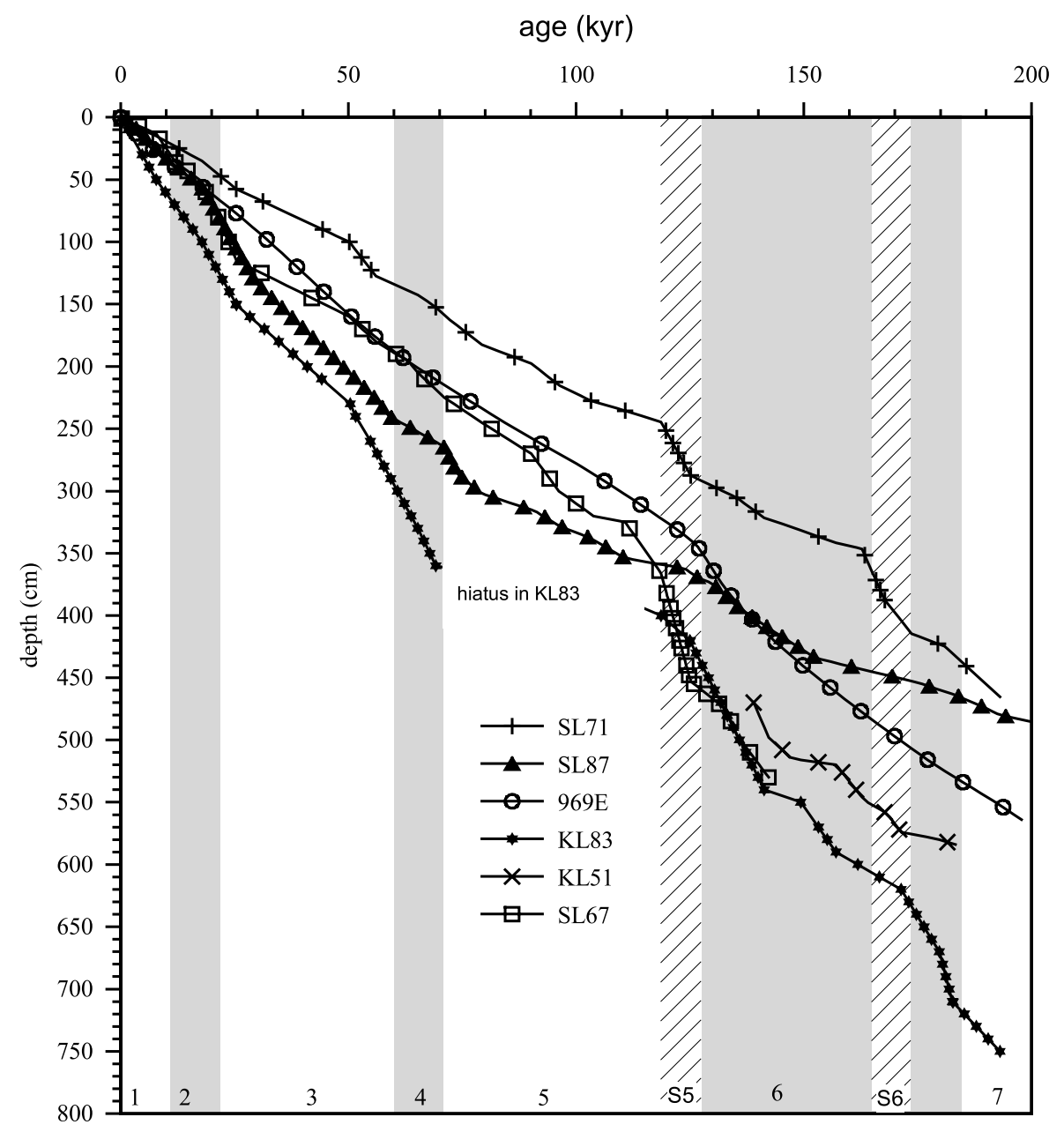

Fig. 3. Age-depth plot showing changes in sedimentation rates. Numbers and gray/white-shaded areas indicate marine oxygen isotope stages. Dashed areas show investigated sapropels. 
ranging from 4 to $7 \mathrm{~cm} / \mathrm{kyr}$. During the glacial phase the deposition rate in KL83 is slightly increased compared to the interglacial interval. In core SL83, however, a decrease in sedimentation rates is observed at times of sapropel formation (Fig. 3). ODP 969E does not show any pronounced changes in sedimentation rates during the investigated time interval and displays an average rate of $2.7 \mathrm{~cm} / \mathrm{kyr}$. Sedimentation rates in SL87 from the Balearic Sea have average values of $3.8 \mathrm{~cm} / \mathrm{kyr}$ in the interval from MIS 1 to MIS 4. In contrast, MIS 5 and MIS 6 have an average sedimentation rate of $1.2 \mathrm{~cm} / \mathrm{kyr}$.

\subsection{Carbonate and TOC contents}

During the deposition of S6 the carbonate contents in all cores increased by $10-20 \mathrm{wt} \%$ (Fig. 4) with respect to non-sapropelic glacial sediments. In SL71 and SL67, the carbonate content does not decline with the cessation of S6, but rather remains on the same level as of S6 for a short time. In KL83 and KL51, an intercalation of a light-colored and relatively organic-poor layer within S6 exhibits reduced carbonate contents $(10 \mathrm{wt} \%)$. In the case of cores SL67/KL51, the decline of the carbonate content during the intra-S6 interval is much more severe compared to core KL83. This is because of dilution by volcanic ash in the intra-S6 interval. In core SL71 and 969E, the intra-S6 intervals do not have reduced carbonate contents. In SL71 and SL67/KL51, the homogenous glacial sediment is characterized by more or less constant carbonate content around $40 \mathrm{wt} \%$. Glacial sediment of $969 \mathrm{E}$ shows depleted carbonate contents of $25 \mathrm{wt} \%$. In contrast to 969E, KL83 exhibits an interval that is carbonate-enriched relative to the immediate underand overlying sediments. In SL87, intervals corresponding to $\mathrm{S} 5$ and $\mathrm{S} 6$ are enriched in $\mathrm{CaCO}_{3}$.

In SL71, 969E, and SL67, the onset of S5 is accompanied by a steep decrease of carbonate content. Low carbonate contents between 10 and $30 \mathrm{wt} \%$ persist throughout the deposition of S5. The sharpest decline in carbonate is observed in 969E and SL67 (Fig. 5), whereas in SL71 the decrease in carbonate is moderate. In contrast, the sapropel section of KL83 is marked by an in-
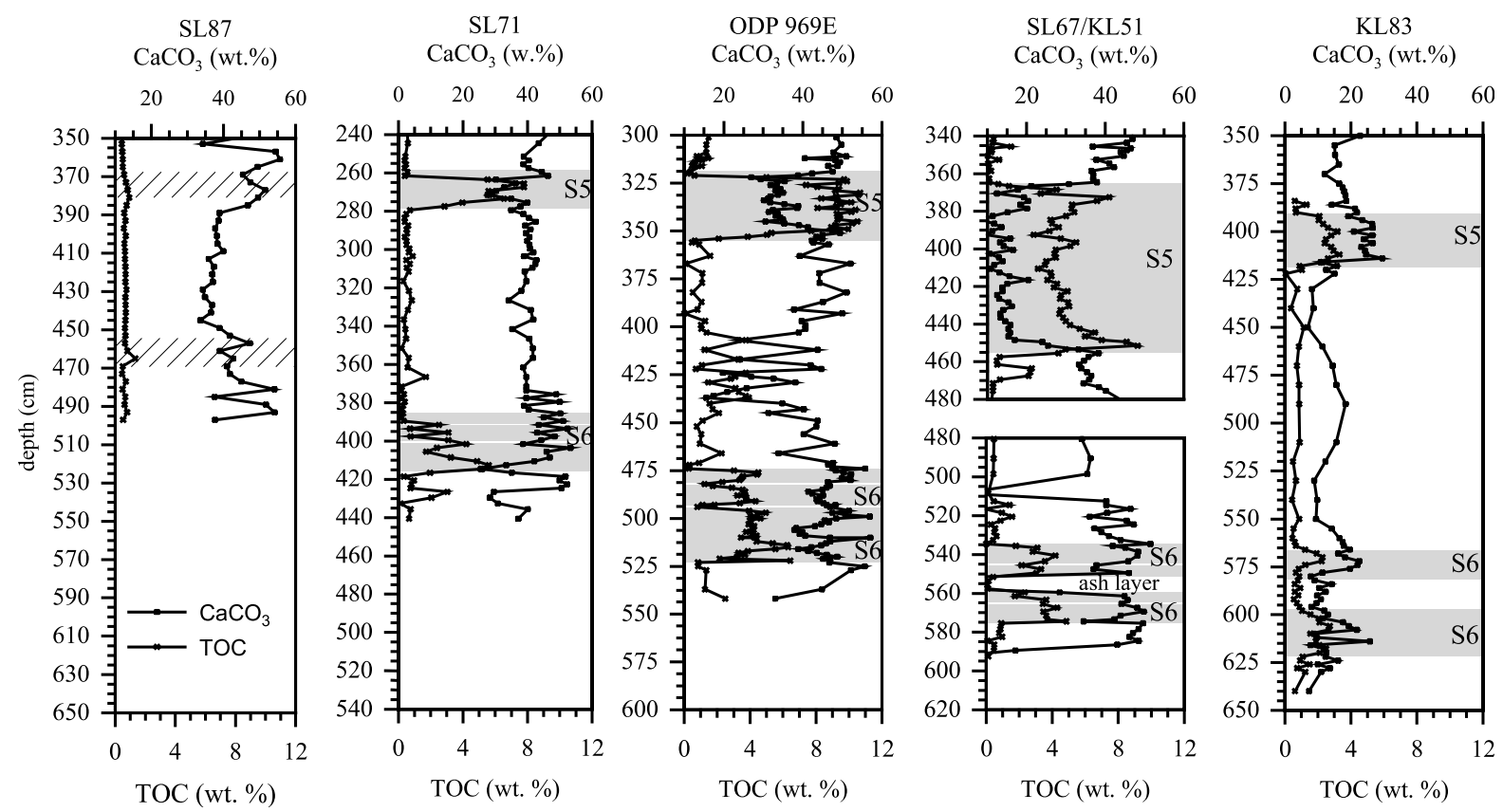

Fig. 4. $\mathrm{CaCO}_{3}$ and TOC content of investigated core sections. EMS sapropels are indicated by dark gray-shaded areas. Chronologically equivalent intervals in the WMS (SL87) are dashed. 


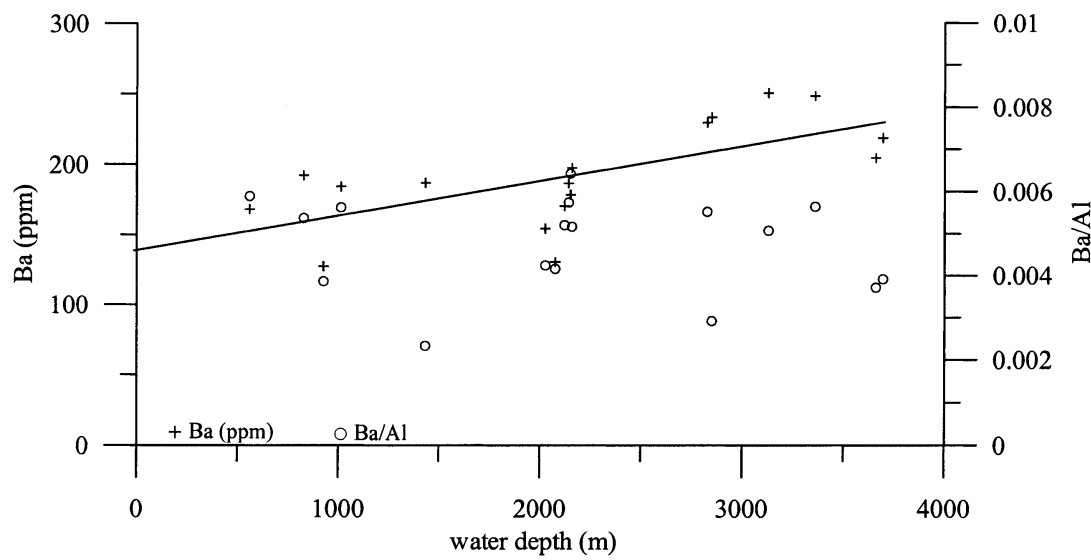

Fig. 5. Ba contents and $\mathrm{Ba} / \mathrm{Al}$ ratios of surface sediments versus water depth. Linear regression line is drawn showing the relationship between $\mathrm{Ba}(\mathrm{ppm})$ and water depth.

crease of the carbonate content by about $27 \mathrm{wt} \%$ relative to sediments beneath the $\mathrm{S} 5$.

The TOC contents vary between 3 and $5 \mathrm{wt} \%$ during S6 in the EMS, with lower TOC contents in KL83. In the WMS, the time-equivalent interval to $\mathrm{S} 6$ shows TOC contents ranging from 0.2 to $0.4 \mathrm{wt} \%$. During S5, TOC contents of the core from the EMS vary between 4 and $11 \mathrm{wt} \%$ (Fig. 4). Very little change of TOC contents (max. 0.45 $\mathrm{wt} \%$ ) is observed during the time-equivalent period to S5 in the WMS.

\subsection{Ba contents in surface sediments}

Ba contents of the surface sediments indicate a slight increase with increasing water depth (Fig. 5, Table 2). However, Ba contents also vary between 154 and $197 \mathrm{ppm}$ within a narrow range of water depth (around $2000 \mathrm{~m}$ ). A linear regression line is computed and it intercepts the ordinate axis at $140 \mathrm{ppm}$. This value theoretically corresponds to the terrigenous $\mathrm{Ba}$ fraction. $\mathrm{Ba} / \mathrm{Al}$ ratios of the surface sediments (Fig. 5), however, hardly show

Table 2

Location, water depth, $\mathrm{Ba}$ contents, and $\mathrm{Ba} / \mathrm{Al}$ ratios of the investigated surface sediments

\begin{tabular}{|c|c|c|c|c|c|}
\hline Sample & $\begin{array}{l}\text { Latitude } \\
\text { (N) }\end{array}$ & $\begin{array}{l}\text { Longitude } \\
\text { (E) }\end{array}$ & $\begin{array}{l}\text { Water depth } \\
\text { (m) }\end{array}$ & $\begin{array}{l}\mathrm{Ba} \\
(\mathrm{ppm})\end{array}$ & $\mathrm{Ba} / \mathrm{Al}$ \\
\hline MUC-66 & $35^{\circ} 36.01$ & $25^{\circ} 54.35$ & 560 & 168 & 0.005 \\
\hline MUC-65 & $36^{\circ} 08.76$ & $25^{\circ} 33.84$ & 828 & 192 & 0.005 \\
\hline ODP 966A & $33^{\circ} 47.79$ & $32^{\circ} 42.95$ & 926 & 127 & 0.003 \\
\hline MUC-75 & $35^{\circ} 48.63$ & $22^{\circ} 40.23$ & 1012 & 184 & 0.005 \\
\hline MUC-213 & $32^{\circ} 36.87$ & $34^{\circ} 08.89$ & 1431 & 187 & 0.002 \\
\hline ODP 971A & $33^{\circ} 43.62$ & $24^{\circ} 40.84$ & 2026 & 154 & 0.004 \\
\hline ODP 970A & $33^{\circ} 44.19$ & $24^{\circ} 48.12$ & 2075 & 130 & 0.004 \\
\hline MUC-68 & $34^{\circ} 41.35$ & $27^{\circ} 16.26$ & 2121 & 170 & 0.005 \\
\hline MUC-70 & $33^{\circ} 42.82$ & $24^{\circ} 42.11$ & 2141 & 186 & 0.005 \\
\hline MUC-69 & $33^{\circ} 51.53$ & $24^{\circ} 51.46$ & 2150 & 178 & 0.006 \\
\hline MUC-67 & $34^{\circ} 48.91$ & $27^{\circ} 17.77$ & 2158 & 197 & 0.005 \\
\hline MUC-71 & $34^{\circ} 48.67$ & $23^{\circ} 11.63$ & 2827 & 229 & 0.005 \\
\hline MUC-77 & $37^{\circ} 00.56$ & $16^{\circ} 17.80$ & 2850 & 233 & 0.002 \\
\hline MUC-72 & $34^{\circ} 18.15$ & $19^{\circ} 53.93$ & 3130 & 250 & 0.005 \\
\hline MUC-76 & $35^{\circ} 13.76$ & $21^{\circ} 29.96$ & 3360 & 248 & 0.005 \\
\hline ODP 964A & $36^{\circ} 15.62$ & $17^{\circ} 44.99$ & 3660 & 204 & 0.003 \\
\hline ODP 973A & $35^{\circ} 46.82$ & $18^{\circ} 56.88$ & 3695 & 218 & 0.003 \\
\hline
\end{tabular}



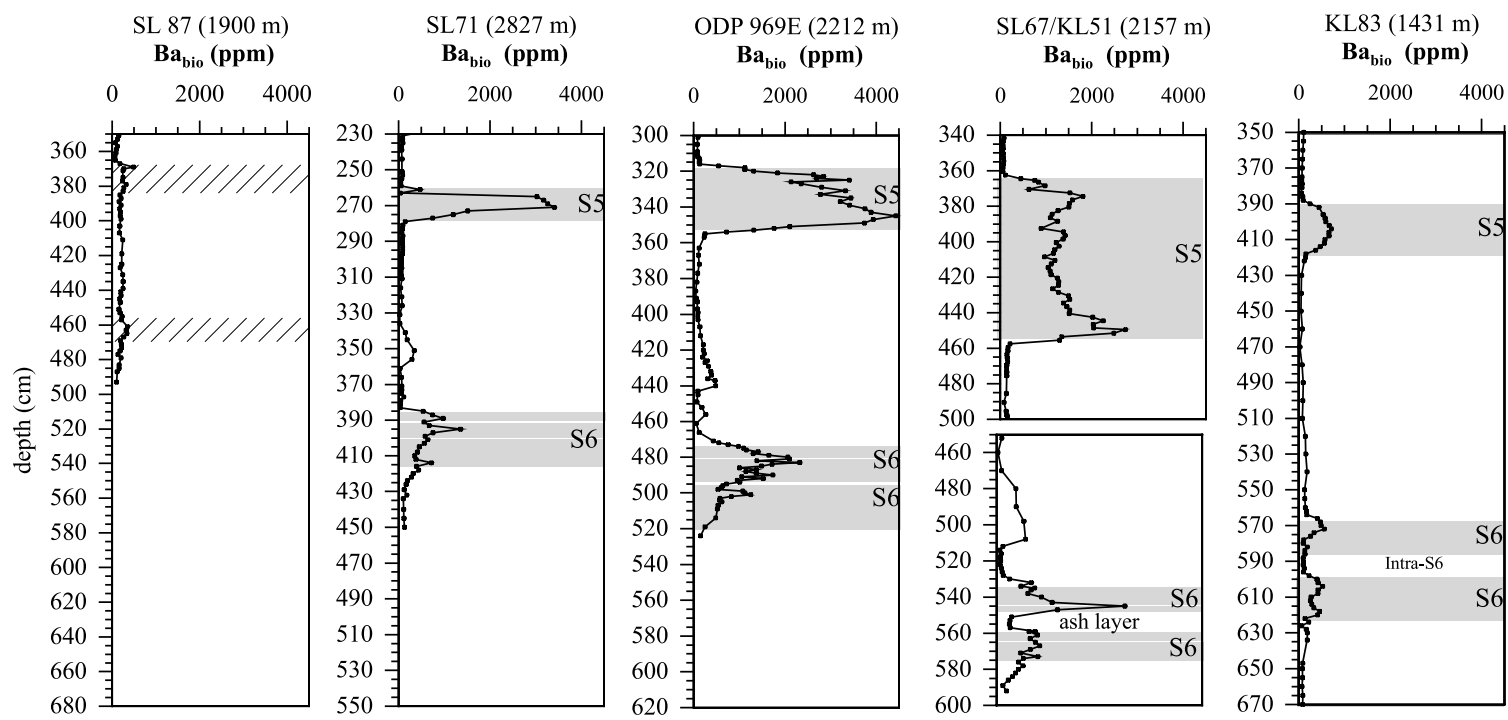

Fig. 6. $\mathrm{Ba}_{\text {bio }}$ concentration (ppm) versus sediment depth of the investigated core sections. Positions of sapropels are dark-shaded. Dashed areas in SL87 indicate interval time-equivalent to S5 and S6 in the EMS.

any relation to water depth. The lowest $\mathrm{Ba} / \mathrm{Al}$ ratio $(=0.002)$ and the theoretically derived $\mathrm{Ba}$ content of $140 \mathrm{ppm}$ yield similar values when used for the correction of the terrigenous Ba fraction. $\mathrm{Ba} / \mathrm{Al}=0.002$ is used for the calculation of $\mathrm{Ba}_{\text {bio }}$.

\subsection{Biogenic barium in the core sections}

Variations of $\mathrm{Ba}_{\text {bio }}$ contents and $\mathrm{Ba}_{\text {bio }}$ accumulation rates $\left(\mathrm{Ba}_{\mathrm{bio}}-\mathrm{AR}\right)$ in the investigated core sections are shown in Figs. 6 and 7, respectively. The sediments of the glacial phase before the onset of S6 display $\mathrm{Ba}_{\text {bio }}$-AR between 0.4 and 1.6 $\mu \mathrm{g} / \mathrm{cm}^{2} / \mathrm{yr}$. The onset of S6 in the EMS and the time-equivalent interval from the Balearic Sea are accompanied by a gradual increase of $\mathrm{Ba}_{\text {bio }}$-AR culminating in values of $2.3 \mu \mathrm{g} / \mathrm{cm}^{2} / \mathrm{yr}$ (KL83), 6.3 $\mu \mathrm{g} / \mathrm{cm}^{2} / \mathrm{yr}$ (KL51), $6.2 \mu \mathrm{g} / \mathrm{cm}^{2} / \mathrm{yr}$ (969E), $2.1 \mu \mathrm{g} /$ $\mathrm{cm}^{2} / \mathrm{yr}$ (SL71), and $0.6 \mu \mathrm{g} / \mathrm{cm}^{2} / \mathrm{yr}$ (SL87). In the EMS, the increase is interrupted by an intercalation called intra-S6. $\mathrm{Ba}_{\text {bio }}-\mathrm{AR}$ in the intra-S6 are lower compared to the upper and lower parts of S6, but much higher than in the sediment intervals beneath and above S6. Core SL71, located west of $969 \mathrm{E}$, displays $\mathrm{Ba}_{\text {bio }}$ values that are lower than those of the corresponding section in 969E. Begin- ning with the onset of the upper part of $\mathrm{S} 6, \mathrm{Ba}_{\mathrm{bio}}$ AR increase up to $2.4 \mu \mathrm{g} / \mathrm{cm}^{2} / \mathrm{yr}$ (KL83), $6.4 \mu \mathrm{g} /$ $\mathrm{cm}^{2} / \mathrm{yr}(\mathrm{KL} 51), 11.4 \mu \mathrm{g} / \mathrm{cm}^{2} / \mathrm{yr}(969 \mathrm{E})$, and $2.9 \mu \mathrm{g} /$ $\mathrm{cm}^{2} / \mathrm{yr}$ (SL71) in the EMS. For the time-equivalent interval in the Balearic Sea (SL87), the highest $\mathrm{Ba}_{\text {bio }}-\mathrm{AR}$ is $0.44 \mu \mathrm{g} / \mathrm{cm}^{2} / \mathrm{yr}$. With cessation of $\mathrm{S} 6$, the $\mathrm{Ba}_{\text {bio }}$ contents return to values comparable to those before the onset of S6. Within the homogenous interval, a moderate increase of $\mathrm{Ba}_{\mathrm{bio}}-\mathrm{AR}$ is observed in the cores SL71 (360-340 cm, max. $\left.1.2 \mu \mathrm{g} / \mathrm{cm}^{2} / \mathrm{yr}\right), 969 \mathrm{E}(445-415 \mathrm{~cm}, \max .3 .10 \mu \mathrm{g} /$ $\mathrm{cm}^{2} / \mathrm{yr}$ ), and KL51 (510-480 cm, max. $3.2 \mu \mathrm{g} / \mathrm{cm}^{2} /$ yr). This interval corresponds stratigraphically to the insolation maximum at $150 \mathrm{kyr}$. In the corresponding section of $\mathrm{KL83}$, the increase of $\mathrm{Ba}_{\text {bio }}$ contents as well as $\mathrm{Ba}_{\mathrm{bio}}-\mathrm{AR}$ are not well-pronounced, showing a maximum of $181 \mathrm{ppm}$ and $1.0 \mu \mathrm{g} / \mathrm{cm}^{2} / \mathrm{yr}$, respectively.

In cores SL67, 969E, and SL71, the onset of S5 deposition is characterized by a sharp rise of $\mathrm{Ba}_{\text {bio }}-\mathrm{AR}$. In these cores, maximum $\mathrm{Ba}_{\text {bio }}-\mathrm{AR}$ is reached in the lower half of the sapropel. It displays values of $10.1 \mu \mathrm{g} / \mathrm{cm}^{2} / \mathrm{yr}$ (SL67), $27.3 \mu \mathrm{g} /$ $\mathrm{cm}^{2} / \mathrm{yr}$ (969E), and $12.1 \mu \mathrm{g} / \mathrm{cm}^{2} / \mathrm{yr}$ (SL71). The distribution pattern of $\mathrm{Ba}_{\mathrm{bio}}-\mathrm{AR}$ within $\mathrm{S} 5$ of KL83 (S5) differs from the cores described above. Here, a gradual increase and decrease of $\mathrm{Ba}_{\mathrm{bio}^{-}}$ 


$\begin{array}{llll}\mathrm{Ba}_{\mathrm{bio}} \mathrm{AR} & \mathrm{Ba}_{\text {bio }} \text { Flux } & \text { Export product. } & \text { Primary product. } \\ \left(\mu \mathrm{g} / \mathrm{cm}^{2} / \mathrm{yr}\right) & \left(\mu \mathrm{g} / \mathrm{cm}^{2} / \mathrm{yr}\right) & \left(\mathrm{gC} / \mathrm{m}^{2} / \mathrm{yr}\right) & \left(\mathrm{gC} / \mathrm{m}^{2} / \mathrm{yr}\right)\end{array}$
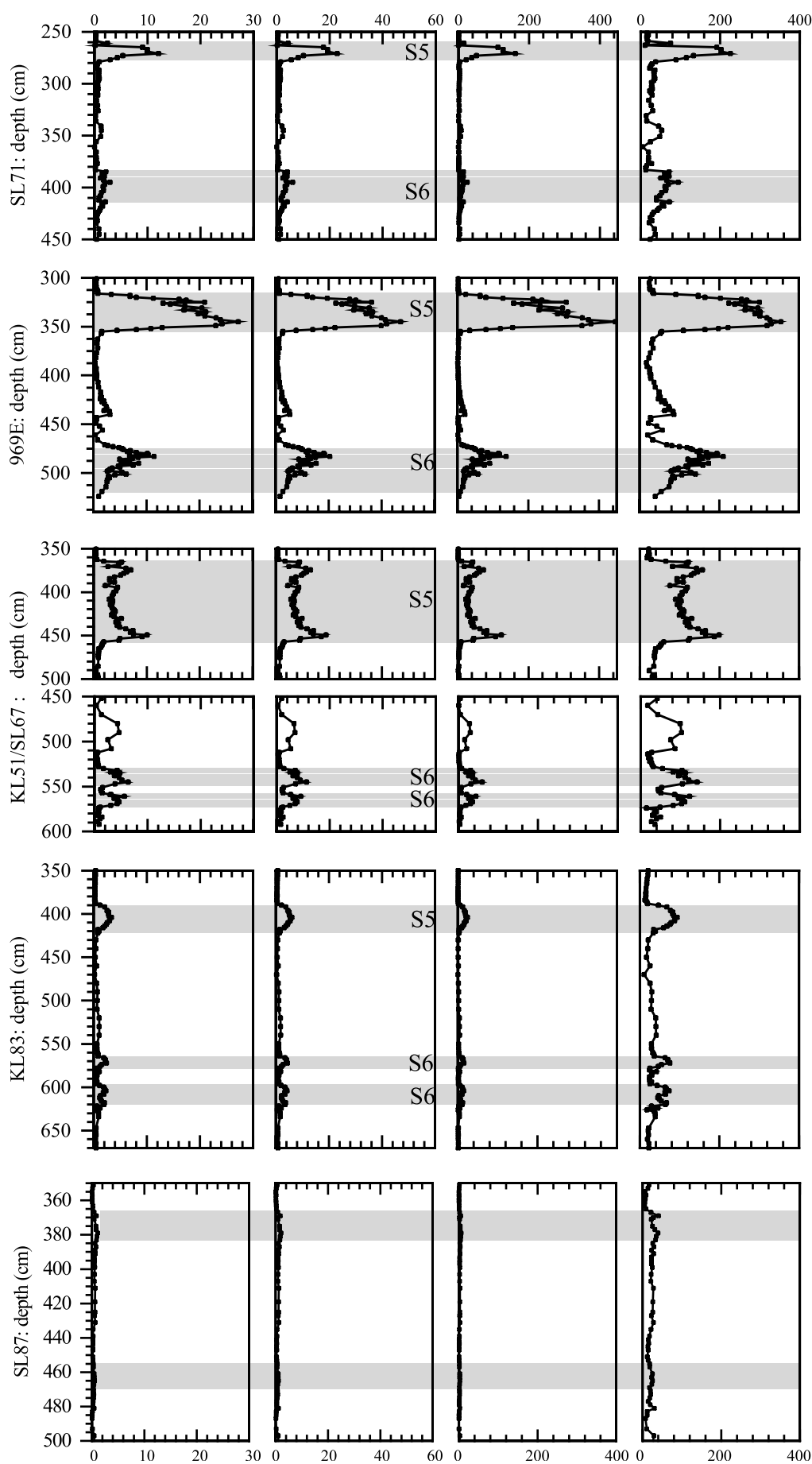

Fig. 7. $\mathrm{Ba}_{\mathrm{bio}_{\mathrm{o}}}-\mathrm{AR}, \mathrm{Ba}_{\mathrm{bio}}-\mathrm{FR}$, export productivity, and primary productivity versus depth in the $\mathrm{S} 5 / \mathrm{S} 6$ core sections from the EMS 
AR are observed at the onset and cessation of S5, respectively. Additionally, the highest $\mathrm{Ba}_{\mathrm{bio}}-\mathrm{AR}$ $\left(3.3 \mu \mathrm{g} / \mathrm{cm}^{2} / \mathrm{yr}\right)$ is observed in the center of S5. In the WMS, the $\mathrm{Ba}_{\text {bio }}$-AR in the time-equivalent interval to $\mathrm{S} 5$ is distinguished by a slight increase (average: $1.1 \mu \mathrm{g} / \mathrm{cm}^{2} / \mathrm{yr}$ ) compared to the underlying sediment sections (average: $0.8 \mu \mathrm{g} / \mathrm{cm}^{2} / \mathrm{yr}$ ).

\section{Discussion and interpretation}

\subsection{Variation of carbonate and TOC contents}

One of the striking aspects revealed by the carbonate analyses is that in the areas southwest, south, and southeast of Crete, S5 carbonate contents are lower relative to the homogenous underlying sediments by up to $20 \mathrm{wt} \%$. In contrast, the carbonate content in S5 of KL83 is increased by up to $27 \mathrm{wt} \%$ relative to the homogenous glacial sediments of MIS 6. Dilution, dissolution, and/or a change in carbonate production could be responsible for the rise and decline of the carbonate fraction. Elevated terrestrial input plays an important role in diluting the carbonate fraction. However, several studies have demonstrated that lithogenic input was generally reduced during sapropel formation (Wehausen and Brumsack, 1999, 2000; Foucault and Mèlières, 2000; Weldeab et al., 2002). Weldeab et al. (2002) showed that terrigenous accumulation rates were reduced from average glacial values of $6 \mathrm{~g} / \mathrm{cm}^{2} / \mathrm{kyr}$ to $2 \mathrm{~g} / \mathrm{cm}^{2} / \mathrm{kyr}$ during S5 as well as during S6 formation in SL67/ KL51. Similar results were obtained by the same authors in core SL71. Thus, dilution due to enhanced terrigenous flux is unlikely to explain the observed pattern. Dissolution of $\mathrm{CaCO}_{3}$ can occur during oxidation of organic matter under oxic as well as anoxic conditions. Because of sediment lamination and absence of benthic foraminifera we assume that anoxic conditions prevailed during S5 formation in SL71, 969E, and SL67/KL51. Sulfate reduction in its early stage may reduce $\mathrm{pH}$ and induce $\mathrm{CaCO}_{3}$ dissolution (van $\mathrm{Os}$ et al., 1994). But if, for instance, the $\mathrm{CaCO}_{3}$ decline in S5 of $969 \mathrm{E}$ was solely caused by dissolution, the observed decrease of $\mathrm{CaCO}_{3}$ from average $47 \mathrm{wt} \%$ $(=47 \mathrm{~g})$ to $15 \mathrm{wt} \%(=9 \mathrm{~g})$, i.e. $80 \%(=38 \mathrm{~g})$
$\mathrm{CaCO}_{3}$ dissolution, requires organic matter oxidation of $4.6 \mathrm{wt} \%(12 / 100$ ([molecular weight of $\left.\mathrm{C}_{\text {org }} / \mathrm{CaCO}_{3}\right] \times 38 \mathrm{~g}=4.6 \mathrm{~g}$ or $\left.4.6 \mathrm{wt} \%\right)$ ). For simplicity, a constant terrigenous flux was assumed which is unlikely for reasons stated above. Considering the lower terrigenous flux during S5, our calculation would yield even higher amounts of organic matter that had to be decomposed. Such intense oxidation of organic matter under anoxic conditions requires pervasive sulfate-reducing conditions. Extensive sulfate reduction will cause alkaline conditions preventing $\mathrm{CaCO}_{3}$ dissolution (van Os et al., 1994). A simplified equation for $\mathrm{CaCO}_{3}$ dissolution from $\mathrm{C}_{\text {org }}$ oxidation and sulfate reduction may be given as follows: $2 \mathrm{CH}_{2} \mathrm{O}+$ $\mathrm{SO}_{4}^{2-} \rightarrow 2 \mathrm{CO}_{2}+\mathrm{S}^{2-}+2 \mathrm{H}_{2} \mathrm{O}$ and $\mathrm{CO}_{2}+\mathrm{CaCO}_{3}+$ $\mathrm{H}_{2} \mathrm{O} \rightarrow 2 \mathrm{HCO}_{3}^{-}+\mathrm{Ca}^{2+}$. Hence, dissolution may have occurred, but the extent of $\mathrm{CaCO}_{3}$ decrease observed in S5 of SL71, 969E and SL67 requires that other processes contributed.

Change in carbonate production may have played an important role in explaining the temporal variations of carbonate contents. It has been shown that in modern settings with high productivity and/or during seasonal phytoplankton blooms the flux of biogenic opal is very high as a result of a dominance of opportunistic planktic diatoms (among others Welling et al., 1992; Romero et al., 1999). Biogenic opal that initially was deposited with sapropels is likely dissolved after the deposition (Kemp et al., 1999). In our cores, this is corroborated by lower $\mathrm{Si} / \mathrm{Al}$ ratios (manuscript in preparation) indicating poorer preservation of biogenic silica and lower input of terrigenous material during sapropel formation as shown by Weldeab et al. (2002). Schrader and Matherne (1981) and Kemp et al. (1999) investigated diatom assemblages and biogenic opal contents of S5 in cores with exceptionally good preservation of biogenic opal recovered south of Crete. According to Kemp et al. (1999), biogenic opal contents account for $17-33 \mathrm{wt} \%$ of the total sapropel sediments suggesting that a higher percentage of the productivity was due to diatom assemblages. These assemblages seem adapted to the exploitation of deep nutrient supply trapped below surface waters within a stratified water column. Considering the findings of the above cited 
authors, the $\mathrm{CaCO}_{3}$ decline of S5 might be explained as the result of a collapse in carbonate productivity and the dominance of opportunistic siliceous plankton over the non-opportunistic, mainly calcareous, plankton. However, S5 in KL83 (easternmost Levantine Basin) and $\mathrm{S} 6$ in all cores display elevated $\mathrm{CaCO}_{3}$ contents and moderate increase of productivity. This result suggests that a moderate productivity increase and the different mode of nutrient delivery to the photic layer probably favored the dominance of non-opportunistic calcareous plankton.

\subsection{Barium as paleoproductivity indicator}

Modern sediments and water columns underlying areas of high surface water productivity are enriched with respect to barite $\left(\mathrm{BaSO}_{4}\right)$, as a carrier of barium (Goldberg and Arrehenius, 1958; Bishop, 1988; Dehairs et al., 1980; Gingele and Dahmke, 1994; Dymond and Collier, 1996; Paytan et al., 1996; Klump et al., 2000). Our results show that in sapropels $\mathrm{Ba}_{\mathrm{bio}}$-AR were increased up to 20 times $\left(27 \mu \mathrm{g} / \mathrm{cm}^{2} / \mathrm{yr}\right)$ relative to the background values ranging between 0.4 and $1.3 \mu \mathrm{g} /$ $\mathrm{cm}^{2} / \mathrm{yr}$. The exact processes responsible for the coupling of surface productivity and Ba enrichments are not yet fully known. However, barite precipitation in sulfate-rich microenvironments associated with decaying organic matter is the preferred explanation (Bishop, 1988; Dehairs et al., 1980). The correlation between enriched barium concentration in sediments and high biological productivity in surface waters has been extended to interpret temporal and spatial productivity changes in the past (Schmitz, 1987; Bonn et al., 1998; Gingele and Dahmke, 1994; Schroeder et al., 1997; Thompson and Schmitz, 1997). Mercone et al. (2000) analyzed a series of atomic mass spectrometry ${ }^{14} \mathrm{C}$-dated cores containing sapropel $\mathrm{S} 1$ in the EMS and pointed out that the spatial variability of $\mathrm{Ba} / \mathrm{Al}$ ratios in sapropel S1 is partially due to the variation in the deposition rates between the sites. We present the variability of $\mathrm{Ba}_{\mathrm{bio}}$ contents and $\mathrm{Ba}_{\mathrm{bio}}-\mathrm{AR}$ (Figs. 6 and 7). The latter takes into account the varying deposition rates and shows pronounced spatial variability indicating that a varying depo- sition rate between the sites does not account for the observed patterns. Before discussing our results in terms of productivity changes, other constraints affecting the barium concentrations and distribution patterns will be addressed.

\subsection{Terrigenous input of $\mathrm{Ba}$ and detrital BalAl ratio}

Varying terrigenous sediment input is a possible explanation for $\mathrm{Ba}$ fluctuation in sediment records. The present oligotrophic conditions of the Mediterranean Sea allow assessment of the terrigenous contribution to the total barium content. The major part of the Ba contents can be attributed to detrital origin due to the oligotrophy of the surface water (Bethoux, 1989). We determined the average terrigenous $\mathrm{Ba}$ contents around 140 ppm and $\mathrm{Ba} / \mathrm{Al}=0.002$ representing the modern climate conditions. This is in good agreement with the results reported by Rutten (2001) and Rutten and De Lange (2002). They determined the fraction of clay- and oxide-bound Ba content, and found that the total $\mathrm{Ba}$ in clay minerals and oxides does not exceed $150 \mathrm{ppm}$ (between $\mathrm{Ba} /$ $\mathrm{Al}=0.003$ and $\mathrm{Ba} / \mathrm{Al}=0.0036$ ). However, the $\mathrm{Ba} /$ $\mathrm{Al}$ ratio varies between $\mathrm{Ba} / \mathrm{Al}=0.003$ and $\mathrm{Ba} /$ $\mathrm{Al}=0.0036$ (Rutten and De Lange, 2002).

\subsection{Ba remobilization during anoxia}

Several studies demonstrated that the applicability of $\mathrm{Ba}$ as paleoproductivity indicator may be limited in anoxic depositional environments. Once sulfate reduction depletes the dissolved sulfate in pore water, barite dissolution and barium remobilization can occur. In such cases Ba fails as paleoproductivity indicator (Brumsack and Gieskes, 1983; Brumsack, 1986; Pruysers et al., 1991; van Os et al., 1991; von Breymann et al., 1992; Falkner et al., 1992; Torres et al., 1996; McManus et al., 1998, 1999). However, the sulfur isotope composition of pyrite in sapropels indicates that sulfate reduction took place in an open system suggesting that dissolved sulfate was never depleted (Passier et al., 1999). It is likely that high concentrations of dissolved sulfate in the EMS deep water/pore water and the high 
porosities of the sapropels facilitate the communication of pore and bottom waters and prevent depletion of dissolved sulfate. Hence, for the reconstruction of productivity changes during sapropel formation, Ba seems applicable (Thomson et al., 1995; van Santvoort et al., 1996; Nijenhuis et al., 1999; Martinez-Ruiz et al., 2000).

Based on the distribution patterns and the absence of 'barite fronts' (high $\mathrm{Ba}$ concentrations above and/or beneath the sapropels) we assume that our data shown in Fig. 6 were originally associated with biological productivity derived from the photic zone. The Ba contents of S5 in KL83, 969E, and SL71 have an approximately Gaussian distribution with maxima in the center of the sapropel and lowest values at the onset and termination of the sapropel. This may indicate the waxing and waning of productivity as emphasized by Thomson et al. (1995). The Ba distribution pattern of S5 in SL67 displays higher concentrations in the lower part and, though less pronounced, in the upper part of the sapropel. It might be argued that $\mathrm{Ba}$ remobilization is responsible for this trend. But given the large extent of the interval that may have been affected by $\mathrm{Ba}$ remobilization, one might expect much higher Ba contents in a supposed 'barite front' (Brumsack and Gieskes, 1983; Torres et al., 1996), which is not the case in SL67. Moreover, deposition rates may explain the observed $\mathrm{Ba}$ distribution. The interval S5 of SL67 displays the highest deposition rates $(13 \mathrm{~cm} /$ kyr) within the whole core. This very high deposition rate would have facilitated the recording of environmental signals in high detail in contrast to equivalent intervals of cores SL71 and 969E exhibiting lower sedimentation rates (Fig. 6). This is in agreement with observations of Emeis et al. (in press) that at the beginning of sapropel formation the depletion of $\delta^{18} \mathrm{O}$ is much stronger than at the middle and upper section of the sapropel.

In core SL87 from the Balearic Sea, anoxia and possible Ba remobilization are unlikely. The presence of very diverse benthic foraminiferal assemblages indicates well-ventilated bottom waters during these intervals. S6 differs from S5 in having moderate $\mathrm{Ba}_{\text {bio }}$ contents and a gradual rise and decline of the $\mathrm{Ba}_{\text {bio }}$ contents at both the onset and end of sapropel formation. It is characterized by less pronounced site-to-site variability. Similar to $\mathrm{S} 5$ there is no indication of $\mathrm{Ba}$ remobilization.

\subsection{Water depth effect on the $B a_{\text {bio }}$ contents}

Several studies indicated a systematic increase of $\mathrm{Ba}_{\text {bio }}$ contents with water depth (Calvert and Price, 1983; von Breymann et al., 1990, 1992; Shimmield, 1992; Dymond et al., 1992; Klump et al., 2000). This finding is attributed to continuous decomposition of organic matter and continuous growth of barite while settling through the water column. Francois et al. (1995) confirmed the water depth dependence of $\mathrm{C}_{\text {org }}: \mathrm{Ba}_{\text {bio }}$ and pointed out the role of lateral contribution of refractory organic matter which could yield higher $\mathrm{C}_{\text {org }}: \mathrm{Ba}_{\text {bio }}$ ratios with depth. On the other hand Dymond and Collier (1996) reported that the variability of Ba flux below $1200 \mathrm{~m}$ water depth is limited. This is consistent with findings of Matrai and Eppley (1989) that sulfur-bearing compounds belong to the most labile organic matter and they are recycled within the upper water column. In the sapropels investigated, especially S5, a pronounced spatial variation of $\mathrm{Ba}$ contents is evident (Fig. 6). According to Dymond and Collier (1996), roughly $75 \%$ of Ba flux at $3800 \mathrm{~m}$ depth originates from above $1200 \mathrm{~m}, 11 \%$ between 1200 and $2100 \mathrm{~m}$, and $14 \%$ between 2100 and $3800 \mathrm{~m}$. Although there are uncertainties in their estimations and different oceanographic conditions, we tentatively use their estimation of $\mathrm{Ba}$ flux and water depth variability. Assuming comparable nutrient availability and surface water productivity during the S5 formation in the EMS and considering a maximum of $25 \% \mathrm{Ba}_{\text {bio }}$ flux difference due to the different water depth between $1431 \mathrm{~m}$ (KL83) and $2212 \mathrm{~m}$ (969E) we obtained a difference of about $29.3 \mu \mathrm{g} / \mathrm{cm}^{2} / \mathrm{yr}$ of $\mathrm{Ba}_{\text {bio }}$-FR between the two cores. SL71 is recovered from deeper water $(2827 \mathrm{~m})$ and shows a lower $\mathrm{Ba}_{\mathrm{bio}} \mathrm{FR}$ than $969 \mathrm{E}(2212 \mathrm{~m})$. If the water depth effect is considered the $\mathrm{Ba}_{\text {bio }}-\mathrm{FR}$ of SL71 is much lower resulting in a difference of $16.5 \mu \mathrm{g} / \mathrm{cm}^{2} / \mathrm{yr}$ when the maximum values of 969E and SL71 are compared. During the deposition of S6, the spatial pattern is quite similar to that of S5, but the magnitude of the $\mathrm{Ba}_{\text {bio }}$ content in each core as 
well as the difference between the sites are lower. Accordingly, the water depth difference between the sites cannot account for the huge difference in $\mathrm{Ba}_{\text {bio }}$ contents and $\mathrm{Ba}_{\text {bio }}$-FR (Figs. 6 and 7) suggesting spatial gradients of nutrient availability and surface water productivity in the EMS at time of S5 deposition.

\subsection{Lateral variability of nutrient availability and surface productivity}

In order to consider the impact of varying deposition rates and bulk dry densities of the sediments, we computed the $\mathrm{Ba}_{\text {bio }}$-AR (Fig. 7). $\mathrm{Ba}_{\text {bio }^{-}}$ FR, export productivity, and primary productivity were also determined applying an algorithm that was developed by Dymond et al. (1992) and modified by Francois et al. (1995) (Fig. 7).

The algorithm has been developed for oxic conditions, hence, it should be applied with care to EMS at times of sapropel formation where the water column was at least partly anoxic. Thus, the absolute values of export and primary productivity may harbor an over-estimation. Nevertheless, the data still reflect a pronounced spatial variability of productivity (Fig. 7). This result raises the question of what mode of nutrient delivery can explain the observed lateral gradients. In the literature, four mechanisms bringing nutrients into the photic zone of the EMS during sapropel formation have been proposed. Calvert (1983), Sarmiento et al. (1988), and Calvert et al. (1992) proposed a nutrient-replete surface water induced by circulation reversal. Upwelling (Schrader and Matherne, 1981; Fontugne and Calvert, 1992) as well as increased riverine nutrient input (Krishnamurthy et al., 2000; Martinez-Ruiz et al., 2000) are also discussed as causes of enhanced primary productivity. Rohling and Gieskes (1989) presented a model of sapropel formation in which pycnocline shoaling allows the incursion of nutrient-enriched IMW into the lower photic zone. This is supported by the occurrence of a planktic flora and fauna adapted to a deep chlorophyll maximum (DCM) at the time of sapropel formation. The idea of pycnocline shoaling (Rohling and Gieskes, 1989; Rohling, 1991, 1994) was adopted by Castradori (1993).

\subsubsection{Sapropel S5}

Riverine nutrients as the sole cause for the high export productivity during S5 is clearly contradicted by our results. In our study, cores that are located closer to entrances of fresh water sources are characterized by moderate $\mathrm{Ba}_{\mathrm{bio}}-\mathrm{AR}$ relative to those distant from fresh water sources. For instance, S5 of KL83 which was recovered from the area directly influenced by Nile water displays $\mathrm{Ba}_{\mathrm{bio}}-\mathrm{AR}$ values (max. $3.3 \mu \mathrm{g} / \mathrm{cm}^{2} / \mathrm{yr}$ ) about eight times lower than S5 in 969E (max. $27.3 \mu \mathrm{g} / \mathrm{cm}^{2} / \mathrm{yr}$ ). Similarly, S5 in SL71 and SL67 from the south of Crete have lower $\mathrm{Ba}_{\mathrm{bio}}$-AR than core 969E. Accordingly, nutrient input by the Nile River is likely to explain the moderate productivity increase at the site of KL83, but for other areas such as south of Crete (969E) further mechanisms of nutrient delivery into the photic zone are required.

Sarmiento et al. (1988) proposed a circulation reversal at times of sapropel formation bringing nutrient-replete IMW to the productive zone. Their suggestion was based on a phosphate box model and on the assumption that sapropels are absent in the WMS indicating low phosphate export from EMS to WMS. However, the existence of sapropels and/or sapropelic sediments have been proven in the WMS since the campaigns of ODP Leg 107 (Kastens et al., 1987; Emeis et al., 1991) and Leg 161 (Comas et al., 1996). The supposed absence of Late Pleistocene sapropels in the WMS does not necessarily imply a low phosphate export from the EMS, but it may reflect that nutrients in the WMS remain below the photic zone by a relatively deep situated pycnocline. Furthermore, Zahn et al. (1987) demonstrated that the Mediterranean outflow water persisted, though it was weakened, throughout the time of sapropel formation.

Shoaling of the pycnocline to the lower part of the photic layer as proposed by Rohling and Gieskes (1989) would partially support the very high export productivity and its spatial variability during S5 (Fig. 7). Once the depth of the surface mixed layer is reduced due to weak wind mixing and the volume of IMW is diminished due to the reduced formation of IMW, the position of the pycnocline/nutricline can be shifted into the lower 
photic zone (Hay, 1995). As soon as the relocation of the pycnocline in the photic zone is established, a DCM develops and the nutricline is decoupled from the pycnocline due to the utilization of nutrients by autotrophs and lies below the DCM (Hayward, 1987; Rohling and Gieskes, 1989). The DCM is maintained by along-isopycnal and cross-isopycnal mixing of nutrients (Hayward, 1987). According to Hayward (1987) alongisopycnal mixing takes place at the base of or below the photic zone and is more important than cross-pycnal mixing in bringing nutrients to the photic zone. However, the pronounced area of highest productivity increase such as south of Crete (969E) requires additional processes to that described above. One possible mechanism is an intensified upward mixing induced by submesoscale cyclonic vortices in this area. Assuming an anti-estuarine but severely weakened circulation pattern compared to the present-day situation (Pinardi and Masetti, 2000) as shown by Myers et al. (1998) for the Holocene sapropel, the cyclonic vortice of the Cretan gyre (Robinson and Golnaraghi, 1993; Roussenov et al., 1995; Pinardi and Masetti, 1998) could have been active and was probably relocated southeast-ward from its present position. The lowest density contrast between surface water and IMW is likely to occur south of Crete due to the distance from fresh water sources and sites of IMW formation where the density contrast is highest (Rohling and Gieskes, 1989). This would favor the formation and maintenance of cyclonic vortices and, hence, continuous upward mixing of nutrient-enriched IMW resulting in primary productivity up to $350 \mathrm{~g} \mathrm{C}^{2} / \mathrm{m}^{2} / \mathrm{yr}$ in the area south of Crete (Fig. 7). In contrast, in areas southwest and southeast of Crete the upward mixing of nutrients might have been moderately and probably temporally (seasonally?) variable. Conditions in the easternmost Levantine Basin at IMW depth should be reflected in KL83 (water depth $1431 \mathrm{~m}$ ). Maximum primary productivity during S5 was nearly one fourth of the productivity increase at the site of $969 \mathrm{E}$ for the same time interval. The site of KL83 likely received high riverine nutrient input due to its relative vicinity to the Nile River mouth during enhanced fresh water discharges. On the basis of the moderate productivity increase relative to other sites, a shoaling of the pycnocline to photic layer at this site (KL83) is questionable. Furthermore, the presence of benthic foraminifera at least across parts of the S5 in KL83 suggests oxygenation at the time of $\mathrm{S} 5$ requiring deep water formation, though probably local and limited (Schmiedl et al., 2003). The deflection of the Nile water masses to the east and along the Israeli-Lebanese coast may have been weakened as a consequence of the weakened North African Current that is one of the driving forces in the present circulation pattern (Pinardi and Masetti, 2002). Subsequently, one could expect that in the northeastern Levantine Basin deep water formation occurred, even though limited and ephemeral, allowing benthic life as evidenced by the occurrence of benthic foraminifera in KL83. The relative order of magnitude and spatial variability of productivity and proposed processes of nutrient delivery in the EMS during S5 are schematically depicted in Fig. 8.

\subsubsection{Homogenous glacial sediments around $150 \mathrm{kyr}$}

As stated in Section 3, the homogenous glacial sediments of the cores from southwest, south, and southeast of Crete display an interval with a noticeable increase of $\mathrm{Ba}_{\mathrm{bio}} \mathrm{AR}$ around $150 \mathrm{kyr}$. In KL51, the rise is up to six-fold higher than in the surrounding sediments (Figs. 6 and 7). A plot of the $\mathrm{Ba}_{\text {bio }}$ concentrations versus the age of sediments and the northern hemisphere $\left(65^{\circ} \mathrm{N}\right)$ summer insolation values (Berger, 1978) for this time interval reveals that the increase of $\mathrm{Ba}_{\text {bio }}$ coincides with the insolation maximum of 506 $\mathrm{W} / \mathrm{m}^{2}$ at $151 \mathrm{kyr}$ (Fig. 9). This insolation maximum is significantly lower when compared to the insolation maxima coinciding with the onset of S5 $\left(548 \mathrm{~W} / \mathrm{m}^{2}\right)$ and $\mathrm{S} 6\left(537 \mathrm{~W} / \mathrm{m}^{2}\right)$. Rossignol-Strick (1985) demonstrated that sapropel formation in the EMS is linked to maximal values of solar radiation in the northern hemisphere. Her insolation or monsoon index, which emphasizes the insolation gradient between the Equator and intertropical convergence zone, has a threshold value of 41 for sapropel formation in the EMS. The insolation index at $150 \mathrm{kyr}$ (29) does not reach 


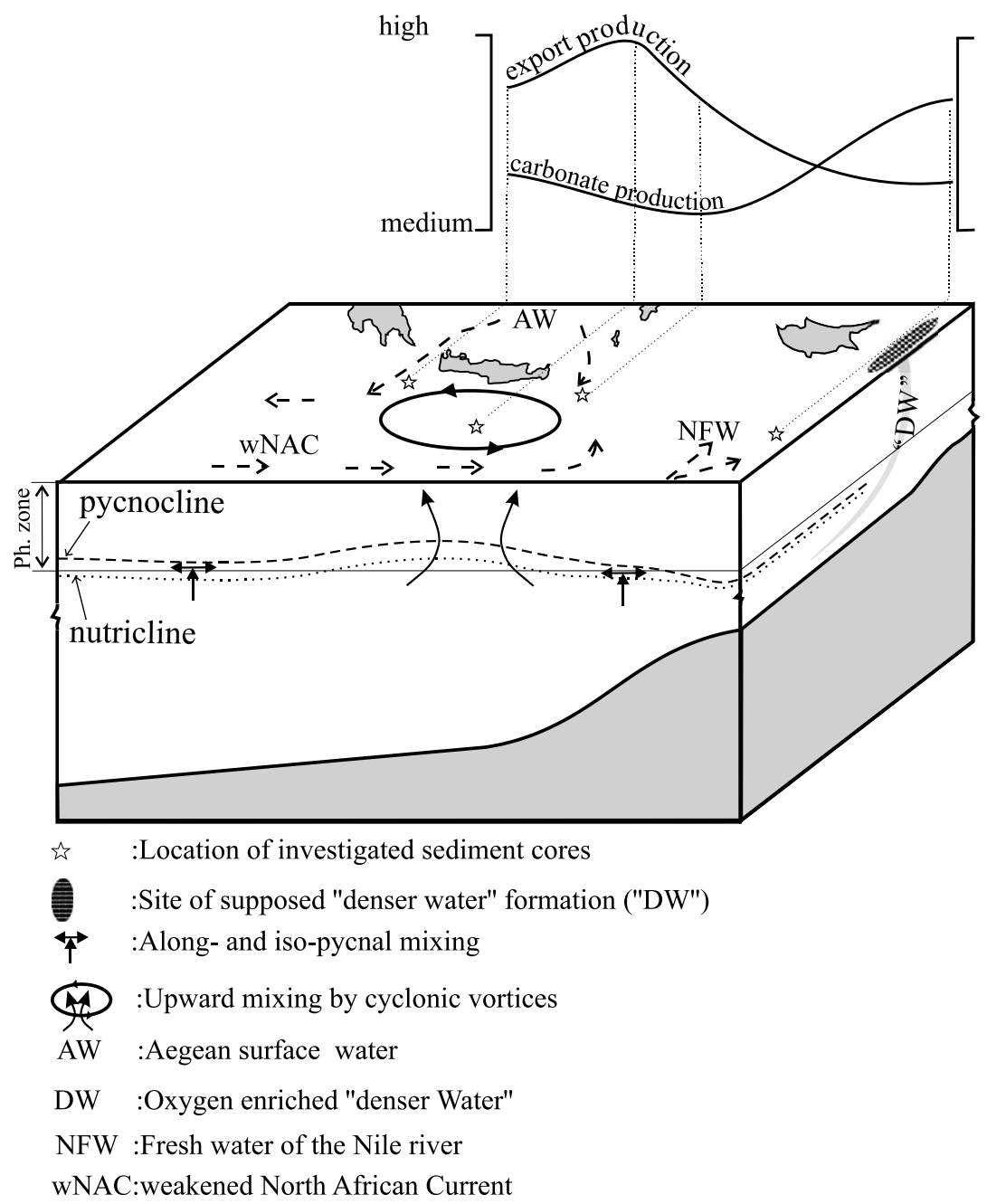

Fig. 8. Schematic illustration of spatial variability of export and carbonate productivities during S5 and proposed mode of nutrient delivery and their magnitude at the different locations.

this threshold and no visible sapropel exists. Van Santvoort et al. (1997) reported high Ba contents and low organic contents in core intervals in the EMS correlating with insolation maxima. They denoted these intervals as 'missing' sapropels and concluded that their observation is a result of postdepositional alterations of sapropels that were deposited under anoxic conditions. For the interval discussed here, the environmental changes induced by the insolation maximum at $150 \mathrm{kyr}$ did give rise to a productivity change that is five to six times higher than during deposition of the surrounding sediments (Fig. 9). However, benthic foraminiferal assemblages indicate that the bottom water remained oxygenated at that time (Schmiedl et al., 1998, 2003). Why this increase of productivity is not pronounced in the easternmost Levantine Basin (KL83) is puzzling. However, it is likely that sampling resolution my have been not high enough to reveal these changes.

\subsubsection{Sapropel S6}

Surface productivity change during S6 is moderate in magnitude. It is characterized by a gradual increase in the early phase of sapropel formation and is balanced in its spatial variability 

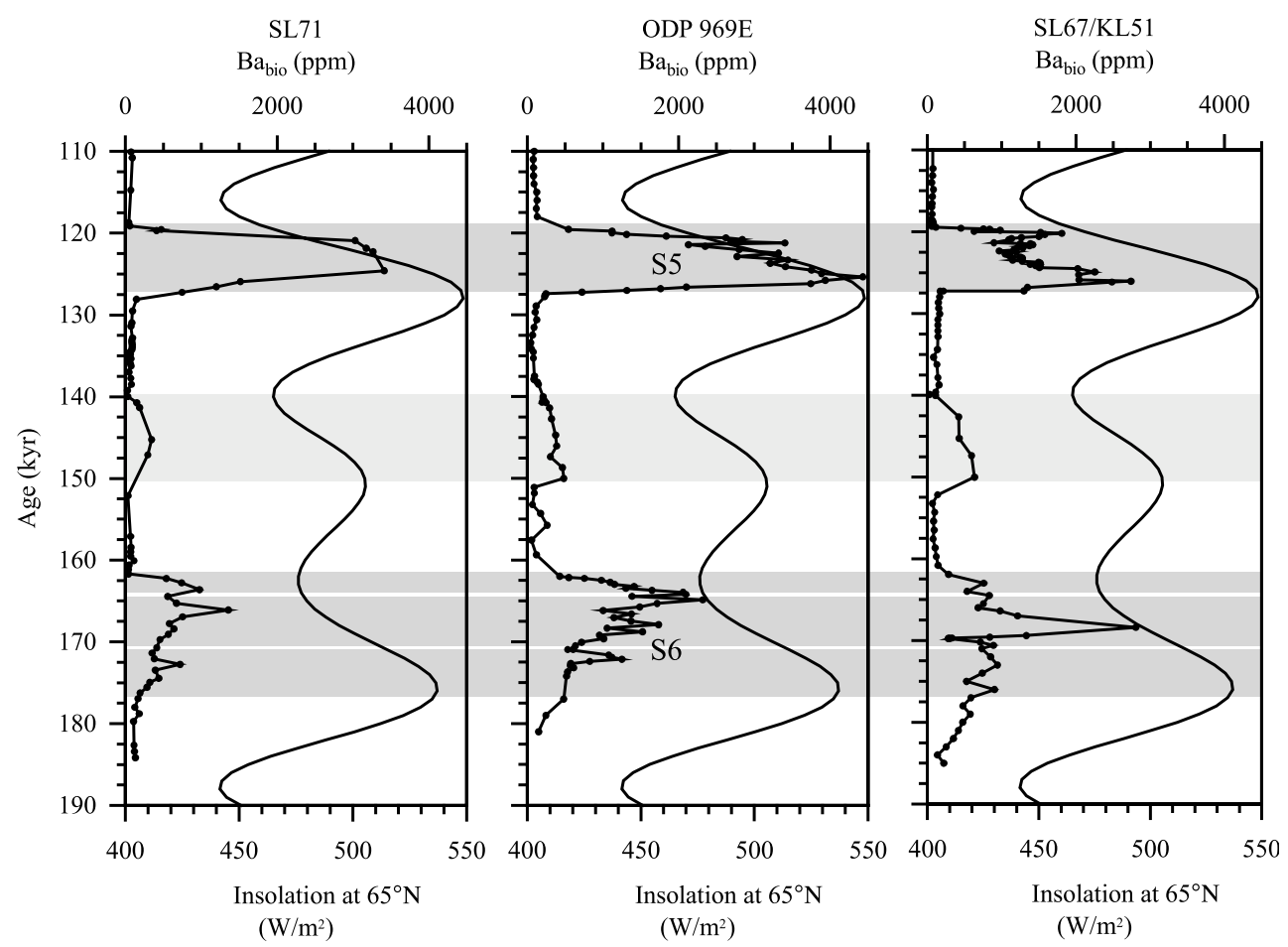

Fig. 9. $\mathrm{Ba}_{\text {bio }}(\mathrm{ppm})$ and northern hemisphere summer insolation (Berger, 1978) versus age in SL71, SL67/KL51, and ODP 969E. Note the different scale of the $\mathrm{Ba}_{\text {bio }}$ axes. Dark gray-shaded areas indicate S5 and S6, light gray-shaded area shows interval of elevated $\mathrm{Ba}_{\text {bio }}$ coinciding with the insolation maximum at $150 \mathrm{kyr}$.

compared to S5 (Fig. 7). Even though S6 is formed during a relatively warmer phase within a glacial interval, surface water temperature reconstructions in the EMS (Emeis et al., 2000a) and palynological investigation in the northern boundary of EMS (NBEM) (Wijmstra et al., 1990; Rossignol-Strick et al., 1998; RossignolStrick and Paterne, 1999) indicate a cool and arid climate during S6. Enhanced wind stress associated with a cool and arid climate may have favored intense mixing of the upper water column minimizing stratification and hydrographic spatial differences within the EMS. Lower surface water temperatures as shown by Emeis et al. (2000a) and Emeis et al. (in press) during S6 promote the presence of denser surface water. Together with wind-induced mixing this may have prevented both permanent water column stratification and permanent anoxia at the sea floor. This suggestion is supported by the occurrence of benthic foraminifera across S6 in cores SL67/
KL51 and KL83. As stated above, a cold and arid climate prevailed at the northern boundary of the EMS. Therefore, enhanced fresh water input from this area is unlikely. Emeis et al. (in press) reported a depletion of $\delta^{18} \mathrm{O}$ of planktonic foraminiferal tests from 'glacial' sapropels (S6 and S8) as well as from the interval around $150 \mathrm{kyr}$. These authors attributed this pattern to the dominant control of the monsoonal system in the southern catchment areas. Considering the productivity changes Castradori (1993) argued that during S6 higher salinities and lower water temperature resulted in much lower density contrasts between surface water and MIW. Thus, he hypothesized a shallower position of the pycnocline than during the formation of the other sapropels (e.g. S5). His conclusion is based on calcareous nannoplankton assemblages in S6 and S8 and S3-S5. While the latter were dominated by a single species (Florisphera profunda) preferring the lower part of the photic zone, during S6 those 
species dominate in the upper part of the photic zone. Our interpretation of the carbonate productivity changes supports this finding, but we are not able to distinguish whether the moderate productivity during S6 is triggered by riverine nutrient input and/or by shifting of the pycnocline into the upper layer of the productive zone as emphasized by Castradori (1993). Given the similarity of productivity $\left(\mathrm{Ba}_{\text {bio }}\right.$ pattern and $\left.\mathrm{CaCO}_{3}\right)$ of $\mathrm{S} 5$ in KL83 and $\mathrm{S} 6$ in all cores, the riverine nutrient input may have played an important role during S6 times in all sites and during S5 times in KL83.

\subsection{4. $W M S$}

In the Balearic Sea (Menorca Rise), changes in surface productivity appear minimal during the sediment intervals chronologically equivalent to S5 and S6 in the EMS. This conclusion is evidenced by an average $\mathrm{Ba}_{\text {bio }}$-AR of $0.9 \mu \mathrm{g} / \mathrm{cm}^{2} / \mathrm{yr}$ for S5 and $0.4 \mu \mathrm{g} / \mathrm{cm}^{2} / \mathrm{yr}$ for S6 versus an average background value of $0.3 \mu \mathrm{g} / \mathrm{cm}^{2} / \mathrm{yr}$ (Fig. 5). These data suggest that productivity changes in the WMS, at least in the investigated area, were low during the investigated time intervals. On the other hand the oxygen isotope signal of planktic foraminiferal tests (Fig. 2) displays $\delta^{18} \mathrm{O}$ depletion on the same order of magnitude as in the EMS. This may be attributed to elevated continental runoff, displacement of atmospheric pressure zones, and salinity and temperature properties of the inflowing North Atlantic surface water (von Grafenstein et al., 1999). However, hydrographic changes in the WMS were not strong enough to induce notable productivity increase either by elevated riverine nutrient input and/or shoaling of the pycnocline.

\section{Summary and conclusions}

$\mathrm{Ba}$, TOC, and carbonate contents of timeequivalent Mediterranean sediment intervals comprising S5 and S6 have been analyzed. The core locations include the Balearic Sea (Menorca Rise), areas around Crete, and the easternmost Levantine Basin. Our data suggest that barium remobilization in sapropel intervals can be excluded, and hence $\mathrm{Ba}$ contents and their spatial distribution patterns are associated with surface productivity and are suitable for reconstructing changes in productivity during times of sapropel formation.

(1) S5 in the EMS: the onset and end of S5 are characterized by rapid rise and abrupt decline of Ba bio contents, respectively. At that time a marked spatial variability of paleoproductivity is ascertained within the EMS. The highest increase in primary productivity was recorded south of Crete. Southwest and southeast of Crete the productivity increase is high and accompanied by a marked decrease in carbonate productivity. In the easternmost Levantine Basin, the productivity increase was moderate and enhanced carbonate productivity is evident. Thus, sites of highest productivity likely favored opportunistic, mostly siliceous, plankton, whereas areas of moderate productivity increase promoted non-opportunistic, mainly calcareous, plankton. The observed spatial variability of productivity could be attributed to different modes of nutrient availability/delivery to the surface water. Riverine nutrient input was responsible for moderate changes in productivity only. At site 969E, distant from fresh water sources and marked by very high paleoproductivity, shoaling of the pycnocline probably resulted in the injection of nutrients from subsurface waters into the photic zone as proposed by Rohling and Gieskes (1989).

(2) Within the homogenous glacial sediments an interval of elevated productivity is detected in all four EMS cores. Chronologically these intervals coincide with the insolation maximum of northern hemisphere summer at $150 \mathrm{kyr}$. Apparently, environmental changes associated with this insolation maximum were insufficient to trigger sapropel formation, but strong enough to induce productivity changes six times higher than during deposition of the surrounding sediments.

(3) S6 in the EMS: paleoproductivity conditions during S6 were moderate and characterized by a gradual increase at the beginning of the sapropel formation compared to S5. Spatial variability is not as pronounced as in S5 and carbonate productivity is elevated. Glacial boundary conditions (i.e. high wind stress, lower surface water temper- 
ature, aridity of the NBEM) may have balanced lateral as well as vertical hydrographic properties resulting in less developed stratification, productivity, and anoxia.

(4) Balearic Sea (Menorca Rise): for the time slices investigated, changes in productivity were relatively small. Apparently, riverine nutrient input and/or other mechanisms of nutrient delivery were insufficient to trigger noticeable productivity changes.

(5) The comparison of interglacial and glacial sapropels reveals the importance of the (high latitude) boundary conditions in determining the development and spatial variability of sapropels within the EMS. Our data suggest different reactions of the WMS and the EMS with respect to northern hemisphere summer insolation and highlights the significance of local phenomena such as location of the catchment areas.

\section{Acknowledgements}

We thank the crew of R/V Meteor for their help and assistance during cruise M40/4, M44/3, and ODP for making sample material available. We also thank Drs. J. Eidam (University of Greifswald) and H. Erlenkeuser for the XRF analyses and stable isotope measurements, respectively. We are indebted to Dr. F.X. Gingele for critical reading of an earlier version of the manuscript and Dr. J.-B. Stuut for improving the English. An anonymous reviewer and Dr. E. Rohling are thanked for their constructive comments and suggestions. This work was funded by the Deutsche Forschungsgemeinschaft Grants to K.-C.E. (Em 37/8) and C.H. (He 697/28). The data discussed in this study are available at Pangaea data base (www.pangaea.de).

\section{References}

Berger, A., 1978. Long-term variations of caloric insolation resulting from the Earth's orbital elements. Quat. Res. 9, 139-167.

Berger, W.H., Smetacek, V.S., Wefer, G., 1989. Ocean productivity and paleoproductivity - an overview. In: Berger, W.H., Smetacek, V.S., Wefer, G. (Eds.), Productivity of the Ocean: Present and Past. Life Science Research Report. John Wiley and Sons, Chichester, pp. 1-34.

Bethoux, J.-P., 1989. Oxygen consumption, new production, vertical advection and environmental evolution in the Mediterranean Sea. Deep-Sea Res. 36, 769-781.

Bishop, J.K.B., 1988. The barite-opal-organic carbon associations in oceanic particulate matter. Nature 332, 341-343.

Bonn, W.J., Gingele, F.X., Grobe, H., Mackensen, A., Fuetterer, D.K., 1998. Palaeoproductivity at the Antarctic continental margin; opal and barium records for the last 400 ka. Palaeogeogr. Palaeoclimatol. Palaeoecol. 139, 195-211.

Brumsack, H.J., 1986. The inorganic geochemistry of cretaceous black shales (DSDP Leg 41) in comparison to modern upwelling sediments from the Gulf of California. In: Summerhayes, C.P., Shakleton, N.J. (Eds.), North Atlantic Palaeoceanography. Geological Society Special Publication 21, pp. 447-462.

Brumsack, J.H., Gieskes, J.M., 1983. Interstitial water tracemetal chemistry of laminated sediments from the Gulf of California, Mexico. Mar. Chem. 14, 89-106.

Calvert, S.E., 1983. Geochemistry of the Pleistocene sediments from the Eastern Mediterranean. Oceanol. Acta 6, 255267.

Calvert, S.E., Nielsen, B., Fontugne, M.R., 1992. Evidence from nitrogen isotope ratios for enhanced productivity during formation of eastern Mediterranean sapropels. Nature 359, 223-225.

Calvert, S.E., Price, N.B., 1983. Geochemistry of Namibian shelf sediments. In: E. Suess, J. Thiede (Eds.), Coastalupwelling: Its sediment record; Part A: Responses of the sedimentary regime to present coastal upwelling. NATO Conference Series. Plenium Press, New York, London, pp. 337375.

Castradori, D., 1993. Calcareous nannofossils and the origin of Eastern Mediterranean sapropels. Paleoceanography 8, 459-471.

Cheddadi, R., Rossignol-Strick, M., 1995. Eastern Mediterranean quaternary paleoclimates from the pollen and isotope records of marine cores in the Nile cone area. Paleoceanography 10, 291-300.

Comas, M.C., Zahn, R., Klaus, A. et al., 1996. Proceedings of the Ocean Drilling Program. Initial Reports, 161.

Dehairs, F., Chesselet, R., Jedwab, J., 1980. Discrete suspended particles of barite and barium cycle in the open ocean. Earth Planet. Sci. Lett. 49, 528-550.

Deuser, W.G., Ross, E.H., 1989. Seasonally abundant planktonic foraminifera of the Sargasso Sea: Succession, deepwater fluxes, isotopic compositions, and paleogeographic implications. J. Foraminifer. Res. 19, 268-293.

Dymond, J., Suess, E., Lyle, M., 1992. Barium in deep-sea sediment: a geochemical proxy for paleoproductivity. Paleoceanography 7, 163-181.

Dymond, J.C., Collier, R., 1996. Particulate barium fluxes and their relationships to biological productivity. Deep-Sea Res. 43, 1283-1308.

Emeis, K.-C., Camerlenghi, A., McKennzie, J.A., Rio, D., Sprovieri, R., 1991. The occurrence and significance of Pleis- 
tocene and Upper Pliocene sapropels in the Tyrrhenian Sea. Mar. Geol., 100, 155-182.

Emeis, K.-C., Robertson, A.H.F., Richter, C. et al., 1996. Proceedings of the Ocean Drilling Program. Initial Reports, 160.

Emeis, K.-C., Sakamoto, T., Wehausen, R., Brumsack, H.-J., 2000a. The sapropel record of the eastern Mediterranean Sea - results of Ocean Drilling Program Leg 160. Palaeogeogr. Palaeoclimatol. Palaeoecol. 158, 371-395.

Emeis, K.-C., Struck, U., Schulz, H.-M., Rosenberg, R., Bernosconi, S., Erlenkeuser, H., Sakanoto, T., Martinez-Ruiz, F., 2000b. Temperature and salinity variations of Mediterranean Sea surface waters over the last 16,000 years from records of planktonic stable oxygen isotopes and alkenone unsaturation ratios. Palaeogeogr. Palaeoclimatol. Palaeoecol. 158, 259-280.

Emeis, K.-C., Schulz, H., Struck, U., Rossignol-Strick, M., Erlenkeuser, H., Howell, M.W., Kroon, D., Mackensen, A., Ishizuka, S., Oba, T., Sakamoto, T., Koizumi, I., in press. Eastern Mediterranean surface water temperatures and $\delta^{18} \mathrm{O}$ composition during deposition of sapropels in the late Quaternary. Paleoceanography.

Emeis, K.-C., Schultz, H.-M., Struck, U., Sakamoto, T., Doose, H., Erlenkeuser, H., Howell, M., Kroon, D., Paterne, M., 1998. Stable isotope and temperature records of sapropels from the ODP Sites 964 and 967: constraining the physical environment of sapropel formation in Eastern Mediterranean Sea. In: A.E.S. Robertson, K.-C. Emeis, C. Richter and A. Camerlenghi (Eds.), Proceeding of the Ocean Drilling Program. Scientific Results, 160. Ocean Drilling Program, College station TX, pp. 309-331.

Falkner, K.K., Klinkhammer, G.P., Browers, T.S., Todd, J.F., Lewis, B.L., Landing, W.M., Edmond, J.M., 1992. The behaviour of barium in anoxic marine waters. Geochim. Cosmochim. Acta 57, 537-554.

Fontugne, M.R., Calvert, S.E., 1992. Late Pleistocene variability of the carbon isotopic composition of organic matter in the Eastern Mediterranean: Monitor of changes in carbon sources and atmospheric $\mathrm{CO}_{2}$. Paleoceanography 7, 1-20.

Foucault, A., Mèlières, F., 2000. Palaeoclimatic cyclicity in central Mediterranean Pliocene sediments: the mineralogical signal. Palaeogeogr. Palaeoclimatol. Palaeoecol. 158, 311323.

Francois, R., Honjo, S., Manganini, S.J., Ravizza, G.E., 1995. Biogenic barium fluxes to the deep sea: Implication for paleoproductivity reconstruction. Glob. Biogeochem. Cycles 9, 289-303.

Gingele, F.X., Dahmke, A., 1994. Discrete barite particles and barium as tracers of paleoproductivity in South Atlantic sediments. Paleoceanography 9, 151-168.

Gingele, F.X., Zabel, M., Kasten, S., Bonn, W.J., Nürnberg, C.C., 1999. Biogenic barium as a proxy for paleoproductivity: Methods and limitations of application. In: Fischer, G., Wefer, G. (Eds.), Use of Proxies in Paleoceanography: Example from the South Atlantic. Springer Verlag, Berlin, pp. 345-364.

Goldberg, E.D., Arrehenius, G.O.S., 1958. Chemistry of Pacif- ic pelagic sediments. Geochim. Cosmochim. Acta 13, 153212.

Hay, W.W., 1995. Paleoceanography of marine organic-carbon-rich sediments. In: Huc, A.-Y. (Ed.), Paleogeography, Paleoclimate, and Source Rock. AAPG Studies in Geology, AAPG, Tulsa, OK, pp. 21-60.

Hayward, T., 1987. The nutrient distribution and primary production in the central North Pacific. Deep-Sea Res. 34, 1593-1627.

Hemleben, C., Spindler, M., Anderson, O.R., 1989. Modern Planktonic Foraminifera. Springer Verlag, pp. 363.

Hilgen, F.J., 1991. Astronomical calibration of Gauss to Matuyama sapropels in the Mediterranean and implication for the Geomagnetic Polarity Time Scale. Earth Planet. Sci. Lett. 104, 226-244.

Kastens, K.A., Mascle, J. et al., 1987. Proceedings of the Ocean Drilling Program. Initial Reports, 107, College Station, TX.

Kemp, A.E.S., Pearce, R.B., Koizumi, I., Pike, J., Rance, S.J., 1999. The role of mat-forming diatoms in the formation of Mediterranean sapropels. Nature 398, 57-61.

Kidd, R.B., Cita, M.B., Ryan, W.B.F., 1978. Stratigraphy of eastern Mediterranean sapropel sequences recovered during DSDP Leg 42A and their paleoenvironmental significance. Deep Sea Drilling Program. Initial Reports 42, 421-443.

Klump, J., Hebbeln, D., Wefer, G., 2000. The impact of sediment provenance on barium-based productivity estimates. Mar. Geol. 169, 259-271.

Krishnamurthy, R.V., Meyers, P.A., Lovan, N.A., 2000. Isotopic evidence of sea-surface freshening, enhanced productivity, and improved organic matter preservation during sapropel deposition in the Tyrrhenian Sea. Geology 28, 263266.

Kullenberg, B., 1952. On the salinity of water contained in marine sediments. Medd. Oceanogr. Inst. Göteberg 21, 138.

Lourens, L.J., Antonarakou, A., Hilgen, F.J., Van Hoof, A.A.M., 1996. Evaluation of the Plio-Pleistocene astronomical timescale. Paleoceanography 11, 391-413.

Martinez-Ruiz, F., Kastner, M., Paytan, A., Ortega-Huertas, M., Bernasconi, S.M., 2000. Geochemical evidence for enhanced productivity during S1 sapropel deposition in the eastern Mediterranean. Paleoceanography 15, 200-209.

Martinson, D.G., Pisias, N.G., Hays, J.D., Imbrie, J., Moore, T.C., Shackleton, N.J., 1987. Age dating and the orbital theory of the Ice Age: Development of a high-resolution 0 to 300,000-year chronostratigraphy. Quat. Res. 27, 1-29.

Matrai, P., Eppley, R., 1989. Particulate organic sulfur in the waters of the southern California Bight. Glob. Biogeochem. Cycles 3, 89-103.

McManus, J., McManus, J., Berelson, W., Klinkhammer, G.P., Johnson, K.S., Coale, K.H., Anderson, R.F., Kumar, N., Burdige, D.J., Hammond, D.E., Brumsack, H.J., McCorkle, D.C., Rushdi, A., 1998. Geochemistry of barium in marine sediments: Implications for its use as a paleoproxy. Geochim. Cosmochim. Acta 62, 3453-3473.

McManus, J., Berelson, W.M., Hammond, D.E., Klinkham- 
mer, G.P., 1999. Barium cycling in the North Pacific: Implications for the utility of $\mathrm{Ba}$ as a paleoproductivity an paleoalkalinity proxy. Paleoceanography $14,53-61$.

Mercone, D., Thomson, J., Croudace, I.W., Siani, G., Paterne, M., Troelstra, S., 2000. Duration of S1, the most recent sapropel in the Eastern Mediterranean Sea, as indicated by accelerator mass spectrometry radiocarbon and geochemical evidence. Paleoceanography 15, 336-347.

Myers, P.G., Haines, K., Rohling, E.J., 1998. Modelling the paleocirculation of the Mediterranean: The last glacial maximum and the Holocene with emphasis on the formation of sapropel S1. Paleoceanography 13, 586-606.

Nijenhuis, I.A., Bosch, H.-J., Sinninghe Damstè, J.S., Brumsack, H.-J., De Lange, G.J., 1999. Organic matter and trace element rich sapropels and black shales: a geochemical comparison. Earth Planet. Sci. Lett. 169, 277-290.

Nijenhuis, J.A., de Lange, G.J., 2000. Geochemical constraints on Pliocene sapropel formation in the eastern Mediterranean. Mar. Geol. 163, 41-63.

Nolet, G.J., Corliss, B.H., 1990. Benthic foraminiferal evidence for reduced deep-water circulation during sapropel in the eastern Mediterranean. Mar. Geol. 94, 109-130.

Olausson, E., 1961. Studies in deep sea cores. Deep Sea Expedition 1947-1948, 8, 337-391.

Paillard, D., Labeyrie, L., Yiou, P., 1996. Macintosh program performs time-series analysis. EOS Trans. AGU 77, 379.

Passier, H.F., Bosch, H.-J., Nijenhius, I.A., Lourens, L.J., Böttcher, M.E., Leenders, A., Damstè, J.S., De Lange, G.J., De Leeuw, J.W., 1999. Sulphidic Mediterranean surface waters during Pliocene sapropel formation. Nature 397, 146-149.

Paytan, A., Kastner, M., Chavez, F.P., 1996. Glacial to interglacial fluctuations in productivity in the Equatorial Pacific as indicated by marine barite. Science 274, 1355-1357.

Pinardi, N., Masetti, E., 2000. Variability of the large general circulation of the Mediterranean Sea from observations and modelling: a review. Palaeogeogr. Palaeoclimatol. Palaeoecol. 158, 153-173.

Pruysers, P., De Lang, G.J., Middelberg, J.J., 1991. Geochemistry of eastern Mediterranean sediments: Primary sediment composition and diagenetic alterations. Mar. Geol. 100, 137-154.

Robinson, A.R., Golnaraghi, M., 1993. Circulation and dynamics of the Eastern Mediterranean Sea; quasi-synoptic data-driven simulations. Deep-Sea Res. 40, 1207-1246.

Rohling, E., 1991. Shoaling of the eastern pycnocline due to reduction of excess evaporation: implication for sapropel formation. Paleoceanography 6, 747-753.

Rohling, E.J., 1994. Review and new aspects concerning the formation of eastern Mediterranean sapropels. Mar. Geol. 122, 1-28.

Rohling, E.J., Gieskes, W.W.C., 1989. Late Quaternary changes in Mediterranean intermediate water density and formation rate. Paleoceanography 4, 531-545.

Rohling, E.J., Hilgen, F.J., 1991. The eastern Mediterranean climate at times of sapropel formation: A review. Geol. Mijnb. 70, 253-264.
Romero, O.E., Lange, C.B., Fischer, G., Treppke, U.F., Wefer, G., 1999. Variability in export production documented by downward fluxes and species composition of marine planktic diatoms: Observations from the tropical and equatorial Atlantic. In: Fischer, G., Wefer, G. (Eds.), Use of Proxies in Paleoceanography: Example from the South Atlantic. Springer Verlag, Berlin, pp. 365-392.

Rossignol-Strick, M., 1983. African monsoons, an immediate climate response to orbital insolation. Nature 304, 46-49.

Rossignol-Strick, M., 1985. Mediterranean Quaternary sapropels, an immediate response of the African monsoon to variation of insolation. Palaeogeogr. Palaeoclimatol. Palaeoecol. 49, 237-263.

Rossignol-Strick, M., Nesteroff, W.D., Olive, P., VergnaudGrazzini, C., 1982. After the deluge: Mediterranean stagnation and sapropel formation. Nature 295, 105-110.

Rossignol-Strick, M., Paterne, M., 1999. A synthetic pollen record of the eastern Mediterranean sapropels of the last $1 \mathrm{Ma}$ : implications for the time-scale and formation of sapropels. Mar. Geol. 153, 221-237.

Rossignol-Strick, M., Paterne, M., Bassinot, F.C., Emeis, K.C., De Lange, G.J., 1998. An unusual mid-Pleistocene monsoon period over Africa and Asia. Nature 392, 269-272.

Roussenov, V., Stanev, E., Artale, V., Pinardi, N., 1995. A seasonal model of the Mediterranean Sea general circulation. Journal of Geophysical Res. 100, 13, 13,515-13,538.

Rutten, A., 2001. A novel selective extraction for barite from marine sediments. Geol. Ultraiectina 202, 113-128.

Rutten, A., De Lange, G.J., 2002. A novel selective extraction of barite, and its application to eastern Mediterranean sediments. Earth Planet. Sci. Lett. 198, 11-24.

Ryan, W.B.F., Cita, M.B., 1977. Ignorance concerning episodes of ocean-wide stagnation. Mar. Geol. 23, 197-215.

Sachs, J.P., Repta, D.J., 1999. Oligotrophy and Nitrogen fixation during Eastern Mediterranean sapropel events. Science 286, 2485-2488.

Sarmiento, J.L., Herbert, T., Toggweiler, J.R., 1988. Mediterranean nutrient balance and episodes of anoxia. Glob. Biogeochem. Cycles 2, 427-444.

Schmiedl, G., Hemleben, C., Keller, J., Segl, M., 1998. Impact of climatic changes on the benthic foraminiferal fauna in the Ionian Sea during the last 330,00 years. Paleoceanography 13, 447-458.

Schmiedl, G., Mitschele, A., Beck, S., Emeis, K.-C., Hemleben, C., Schulz, H., Sperling, M., Weldeab, S., 2003. Benthic foraminiferal record of ecosystem variability in the eastern Mediterranean Sea during times of sapropel $\mathrm{S}_{5}$ and $\mathrm{S}_{6}$ deposition. Palaeogeogr. Palaeoclimatol. Palaeoecol. 190, 139164.

Schmitz, B., 1987. Barium, equatorial high productivity, and the northward wandering of the Indian continent. Paleoceanography 2, 63-77.

Schrader, H., Matherne, A., 1981. Sapropel formation in the eastern Mediterranean Sea: Evidence from preserved opal assemblage. Micropaleontology 27, 191-203.

Schroeder, J.O., Murray, R.W., Leinen, M., Pflaum, R.C., Janecek, T.R., 1997. Barium in equatorial Pacific carbonate 
sediment: Terrigenous, oxide, and biogenic associations. Paleoceanography $12,125-146$.

Shimmield, G.B., 1992. Can sediment geochemistry record changes in coastal upwelling palaeoproductivity? Evidence from northwest Africa and the Arabian Sea. In: Summerhayes, C.P., Prell, W.L., Emeis, K.C. (Eds.), Upwelling Systems: Evolution Since the Early Miocene. Geological Society Special Publication 64, pp. 29-46.

Tang, C., Scott, L.D., 1993. Seasonal salinity changes during Mediterranean sapropel deposition 9000 years B.P.: Evidence from isotopic analyses of individual planktonic foraminifera. Paleoceanography 8, 473-493.

Thompson, E.I., Schmitz, B., 1997. Barium and the late Paleocene $\delta^{13} \mathrm{C}$ maximum: Evidence of increased marine surface productivity. Paleoceanography 12, 239-254.

Thomson, J., Higgs, N.C., Wilson, T.R.S., Croudace, I.W., De Lange, G.J., Santvoort, P.J.M., 1995. Redistribution and geochemical behaviour of redox-sensitive elements around $\mathrm{S} 1$, the most recent eastern Mediterranean sapropel. Geochim. Cosmochim. Acta 59, 3487-3501.

Thomson, J., Mercone, D., De Lange, G.J., van Santvoort, P.J.M., 1999. Reviews of recent advances in the interpretation of eastern Mediterranean sapropel S1 from geochemical evidence. Mar. Geol. 153, 77-89.

Torres, M.E., Brumsack, H.J., Bohrmann, G., Emeis, K.-C., 1996. Barite fronts in continental margin sediments: A new look at barium remobilization in the zone of sulfate reduction and formation of heavy barites in diagenetic fronts. Chem. Geol. 127, 125-139.

van Os, B.J.H., Lourens, L.J., Hilgen, F.J., De Lange, G.J., Beaufort, L., 1994. The Formation of Pliocene and carbonate cycles in the Mediterranean: Diagenesis, dilution, and productivity. Paleoceanography 9, 601-617.

van Os, B.J.H., Middelburg, J.J., De Lange, G.J., 1991. Possible diagenetic mobilisation of barium in sapropelic sediment from the eastern Mediterranean. Mar. Geol. 100, 125-136.

van Santvoort, P.J.M., De Lange, G.J., Thomson, J., Cussen, H., Wilson, T.R.S., Krom, M.D., Ströhle, K., 1996. Active post-depositional oxidation of the recent sapropel (S1) in sediments of the eastern Mediterranean Sea. Geochim. Cosmochim. Acta 60, 4007-4024.

van Santvoort, P.J.M., De Lange, G.J., Langereis, C.G., Dekkers, M.J., Paterne, M., 1997. Geochemical and paleomagnetic evidence for occurrence of 'messing' sapropels in eastern Mediterranean sediments. Paleoceanography 12, 773786.

Vergnaud-Grazzini, C., Ryan, W., Cita, M.B., 1977. Stable isotopic fractionation, climate change and episodic stagnation in the Eastern Mediterranean during the Late Quaternary. Mar. Micropaleontology 2, 353-370.

von Breymann, M.T., Emeis, K.-C., Camerlenghi, A., 1990. Geochemistry of sediments from the Peru upwelling area: Results from the Sites 680, 682, 685, and 688. Proceedings of the Ocean Drilling Program, Scientific Results 112, 491503 .

von Breymann, M., Emeis, K.-C., Suess, E., 1992. Water depth and diagenetic constraints on the use of barium as a palaeoproductivity indicator. In: Summerhayes, C.P., Prell, W.L., Emeis, K.-C. (Eds.), Upwelling Systems: Evolution since the Early Miocene. Geological Society Special Publication 64, pp. 29-46.

von Grafenstein, R., Zahn, R., Tiedemann, R., Murat, A., 1999. Planktonic $\delta^{18}$ O Records at sites 976 and 977, Alboran Sea: stratigraphy, forcing, and paleoceanographic implications. In: Zahn, R., Comas, M.C., Klaus, A. (Eds.), Proceedings of the Ocean Drilling Program. Scientific Results, 161, pp. 469-479.

Wehausen, R., Brumsack, H.-J., 1999. Cyclic variations in the chemical composition of the eastern Mediterranean Pliocene sediments: a key for understanding sapropel formation. Mar. Geol. 153, 161-176.

Wehausen, R., Brumsack, H.-J., 2000. Chemical cycles in The Pliocene sapropel-bearing and sapropel-barren eastern Mediterranean sediments. Palaeogeogr. Palaeoclimatol. Palaeoecol. 158, 325-352.

Weldeab, S., Emeis, K.-C., Hemleben, C., Schulz, H., Vennemann, T.W., 2002. Sr, Nd isotope composition of Late Pleistocene sapropels and non-sapropel sediments from the Eastern Mediterranean Sea: Implications for detrital influx and climatic conditions in the source areas. Geochim. Cosmochim. Acta 66, 3585-3598.

Welling, A., Pisias, N.G., Roelfs, A.K., 1992. Radiolarian microfauna in the northern California Current System: indicators of multiple processes controlling productivity. In: Summerhayes, C.P., Prell, W.P., Emeis, K.-C. (Eds.), Upwelling Systems: Evolution since the Miocene. Geological Special Publication 64, pp. 177-195.

Wijmstra, T.A., Young, R., Witte, H.J.L., 1990. An evaluation of the climatic conditions during the Late Quaternary in northern Greece by means of multivariate analysis of palynological data and comparison with recent phytosociological and climatic data. Geol. Mijnb. 69, 243-251.

Zahn, R., Sarnthein, M., Erlenkeuser, H., 1987. Benthic isotope evidence for changes of the Mediterranean outflow during the Late Quaternary. Paleoceanography 2, 543-559. 